\title{
Par Pond Fish, Water, and Sediment Chemistry
}

by

M. H. Paller

Westinghouse Savannah River Company

Savannah River Site

Aiken, South Carolina 29808

L. D. Wike

DOE Contract NO. DE-AC̣09-89SR18035

This paper was prepared in connection with work done under the above contract number with the U.S.

Department of Energy. By acceptance of this paper, the publisher and/or recipient acknowledges the U.S. Government's right to retain a nonexclusive, royalty-free license in and to any copyright covering this paper, along with the right to reproduce and to authorize others to reproduce all or part of the copyrighted paper. 


\section{DISCLAIMER}

This report was prepared as an account of work sponsored by an agency of the United States Government. Neither the United States Government nor any agency thereof, nor any of their employees, makes any warranty, express or implied, or assumes any legal liability or responsibility for the accuracy, completeness, or usefulness of any information, apparatus, product, or process disclosed, or represents that its use would not infringe privately owned rights. Reference herein to any specific commercial product, process, or service by trade name, trademark, manufacturer, or otherwise does not necessarily constitute or imply its endorsement, recommendation, or favoring by the United States Government or any agency thereof. The views and opinions of authors expressed herein do not necessarily state or reflect those of the United States Government or any agency thereof.

This report has been reproduced directly from the best available copy.

Available to DOE and DOE contractors from the Office of Scientific and Technical Information, P.O. Box 62, Oak Ridge, TN 37831; prices available from (615) 576-8401.

Available to the public from the National Technical Information Service, U.S. Department of Commerce; 5285 Port Royal Road, Springfield, VA 22161. 


\section{DISCLAIMER}

Portions of this document may be illegible electronic image products. Images are produced from the best available original document. 


\section{Table of Contents}

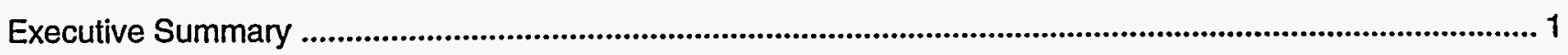

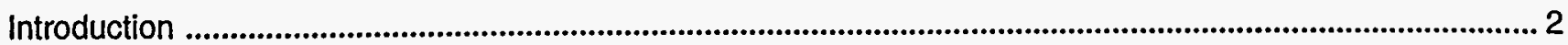

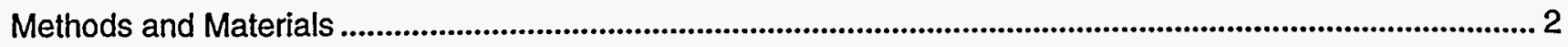

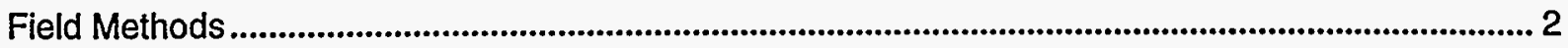

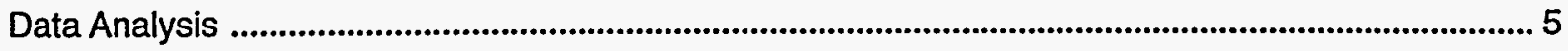

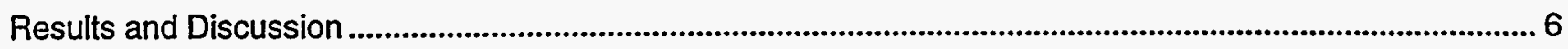

Par Pond Fish Communities ........................................................................................................ 6

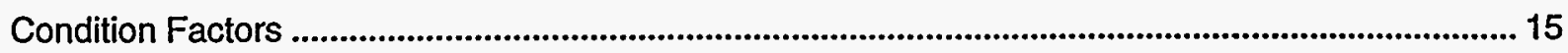

Contaminants in Par Pond Fish .................................................................................................... 16

Contaminants in Par Pond Sediments and Water ...................................................................... 19

Anticipated Effects of Fluctuating Water Level on the

Par Pond Fish Community .............................................................................................................................. 20

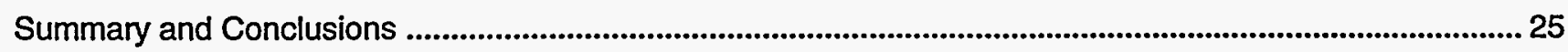

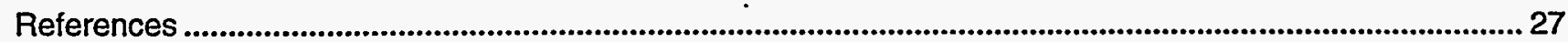

Appendix A: Common and Scientific Names of Par Pond Fish 


\title{
Par Pond Fish, Water, and Sediment Chemistry
}

\author{
M. H. Paller and L. D. Wike \\ Westinghouse Savannah River Company \\ Savannah River Technology Center \\ Environmental Sciences Section \\ Aiken, SC 29808
}

\section{Executive Summary}

For the first 30 years of its existence, Par Pond received heated effluent from one or more nuclear reactors. It was also inadvertently contaminated with low levels of mercury and radionuclides, primarily cesium-137. Despite these impacts, Par Pond supported a diverse, self-sustaining, and relatively stable community of fishes generally similar to the fish communities found in other southeastern reservoirs.

From 1991 to 1995, the water level of Par Pond was drawn down approximately 6 meters ( 20 feet), resulting in a $50 \%$ reduction in surface area, a $65 \%$ reduction in volume, and the temporary elimination of the littoral zone. The four-year drawdown adversely affected the Par Pond fish community as indicated by significant reductions in the average number of fish and number of fish species. However, these effects were temporary. Within seven months of Par Pond refilling to its former level, the number of fish species, number of fish, and relative abundance of fish had returned to pre-drawdown levels. The rapid recovery of the Par Pond fish community demonstrated its resiliency to the effects of water level changes. Factors that contributed to this resiliency included the ability of fish to rapidly recolonize newly inundated habitat, high reproductive capacity, and the rapid regrowth of aquatic vegetation, which provided cover for juvenile fishes in formerly exposed areas.

There was concern that erosion of exposed shoreline during the drawdown, possible resuspension of sediments during the refill, and biological and chemical changes associated with the drawdown and refill might result in greater contamination of Par Pond organisms. However, as of late 1995, there was no evidence of increased contaminant concentrations in Par Pond largemouth bass. Similarly, there was no evidence of increased contaminant levels in Par Pond water or of gross changes in the distribution of contaminants in the Par Pond sediments.

Current plans to shut down the Savannah River Site river water distribution system would cause the water level of Par Pond to fluctuate by as much as several feet in response to seasonal changes in rainfall and evaporation. Considerable research on the effects of fluctuating water levels in other reservoirs indicates that fluctuations are not harmful and may even be beneficial if they are not extreme and match the fluctuations generally characteristic of a normal hydrologic cycle (i.e., high in spring and low in late fall and early winter). Fluctuations in the water level of Par Pond, because they would be determined largely by local weather patterns, would follow natural patterns, although there may be some years in which low water levels during the spring could reduce fish reproductive success. However, as the drawdown studies have demonstrated, such effects are likely to be temporary due to the resiliency of the Par Pond fish community. The drawdown studies also indicate that fluctuations in the water level of Par Pond are unlikely to increase contaminant levels in Par Pond biota or result in longterm resuspension of contaminants in the water column. In summary, natural water level fluctuations of several feet in Par Pond are unlikely to deleteriously affect the Par Pond fish community. 


\section{Introduction}

Par Pond is a 1012-hectare (2500-acre) reservoir on the Savannah River Site (SRS) that was created in 1958 by impounding the upper reaches of Lower Three Runs. Par Pond served as a cooling reservoir for $P$ and $R$ Reactors until 1964 when $R$ Reactor was shut down (Wilde 1985). It continued to receive heated cooling water from P Reactor until 1988. During the early periods of $P$ and $R$ Reactor operations, radioactive materials, chiefly cesium-137, were inadvertently released into the Par Pond ecosystem where they can still be detected in sediments, water, and biota (Gladden et al. 1985). While not a consequence of SRS operations, elevated levels of mercury also occur in Par Pond biota. This mercury probably entered Par Pond in water pumped from the Savannah River (Newman and Messier 1994). Despite its use as a cooling reservoir and inadvertent contamination, Par Pond has historically supported diverse and abundant assemblages of fish and other aquatic biota (Wilde 1985).

In 1991 the water level of Par Pond was reduced from its historic level of 61 meters ( 200 feet) above mean sea level (msl) to 55 meters (181 feet) above msl because of a defect in the Par Pond dam. The drawdown began in June 1991 and the water level reached $55 \mathrm{~m}$ (181 feet) by September 1991. The dam was repaired and Par Pond was refilled to its previous level in early 1995. Par Pond was extensively studied before, during, and after the drawdown, resulting in the generation of considerable information concerning contaminant levels in the Par Pond ecosystem and ecological changes resulting from the drawdown.

Because the nuclear reactors on SRS are no longer operating, the water distribution system that supplied them with cooling water from the Savannah River may be temporarily or permanently shut down. As a result, make-up water to compensate for that lost to evaporation or seepage will no longer be pumped from the Savannah River to Par Pond, and the reservoir will no longer be artificially maintained at a relatively constant 61 meters $(200 \pm 1$ foot) above msl. Hydrologic models indicate that the watershed of Par Pond is large enough to maintain the average water level near historical levels, but fluctuations of several feet or more are expected (COE 1994). There is concern that these fluctuations will adversely affect the ecology of Par Pond. Insights into possible ecological effects of this fluctuating water level scenario can be gleaned by examining the effects of the 1991-1995 drawdown.

The objectives of this report are to:

- describe the Par Pond fish community and the impact of the drawdown and refill on the community,

- describe contaminant levels in Par Pond fish, sediments, and water and indicate how contaminant concentrations and distributions were affected by the drawdown and refill, and

- predict possible effects of future water level fluctuations in Par Pond.

\section{Methods and Materials}

\section{Field methods}

Fish community data from Par Pond were separated into six time periods: pre-drawdown, drawdown 1991, drawdown 1992, refill, spring postrefill, and fall post-refill (Table 1). Fish were collected in all time periods from the north arm, middle arm, west arm, and near the Par Pond dam (Figure 1). Six hundred meters (2000 feet) of shoreline were electrofished at each of the four locations (300 meters [ 980 feet] along each bank, Figure 1). Sampling was generally conducted parallel to the shoreline along the 1-to 2-meter depth contours. The same general areas were sampled during each collection, although the exact locations of the electrofishing sites varied slightly.

Electrofishing was conducted from an aluminum boat. Electrofishing equipment with approximately the same performance specifications was used dur- 
Table 1. Information on fish community samples collected in conjunction with the Par Pond drawdown. Par Pond was drawn down in June 1991 and refilled in early 1995.

\begin{tabular}{|c|c|c|}
\hline Sample period & Frequency & Description \\
\hline January 1984-June 1985 & monthly & pre-drawdown ${ }^{\mathrm{a}}$ \\
\hline 1991 & 3 times a yearb & drawdownc \\
\hline 1992 & 3 times a year $^{b}$ & drawdownc \\
\hline January 1995 & once & refilld \\
\hline May and June 1995 & once & spring post-refill $a$ \\
\hline October 1995 & once & fall post-refill $\mathbf{a}$ \\
\hline
\end{tabular}

a Reservoir water level $=200$ feet above $\mathrm{msl}$.

b . Spring, late summer, and winter.

c Reservior water level $=181$ feet above msl.

d Reservior water level approximately 190 feet above msl.

ing all collection periods. One pass was màde along the length of each transect on a single sample date in each of the last five time periods, and as many fish as possible were collected without regard to species or size. Except for specimens kept for analysis of mercury and cesium-137 body burdens, all captured fish were returned to the water after being identified, weighed, and measured (total length). Aggregate weights and ranges of lengths were usually determined for small species present in large numbers (e.g., brook silverside [Labidesthes sicculus]). Pre-drawdown data were summarized from a study done on the Par Pond fish community between January 1984 and June 1985.

Individuals of several of the most abundant large species in Par Pond (largemouth bass [Micropterus salmoides], bluegill [Lepomis macrochirus], and lake chubsuckers [Erimyzon sucetta]) were analyzed for whole body burdens of mercury and cesium-137. The tissue mass required for these analyses was approximately 300 grams (10.5 ounces) per sample. This quantity usually was obtained from individual specimens in the case of largemouth bass and lake chubsuckers. However, for smaller bass and chubsuckers it was necessary to composite two or more individuals to get the required amount of tissue. Composited samples in- cluded fish of approximately the same total length so that it would be possible to assess relationships between contaminant body burdens and fish size. In the case of bluegill, it was usually necessary to composite a number of specimens to obtain the required 300 grams (10.5 ounces). To the extent possible, only bluegill of similar total length were composited. Individual fish were homogenized in a blender to produce composite samples. Fish collected for contaminant analysis were immediately placed on ice, frozen within several hours of capture, and shipped on ice to qualified laboratories for analysis.

Water samples were collected from Par Pond in September 1995 for analysis of total mercury, gamma emissions (gamma-pulse-height analysis), gross alpha emissions, beta emissions from nonvolatile radionuclides (nonvolatile beta) and U.S. Environmental Protection Agency (EPA) target analyte list metals. Near-top and near-bottom samples were collected from the north arm, middle arm, west arm, and near the Par Pond dam (Figure 1). The samples were collected with a pump and hose system that was thoroughly flushed between samples. The water was collected in previously prepared bottles containing appropriate preservatives and was placed on ice after collection for shipment to analytical laboratories. 


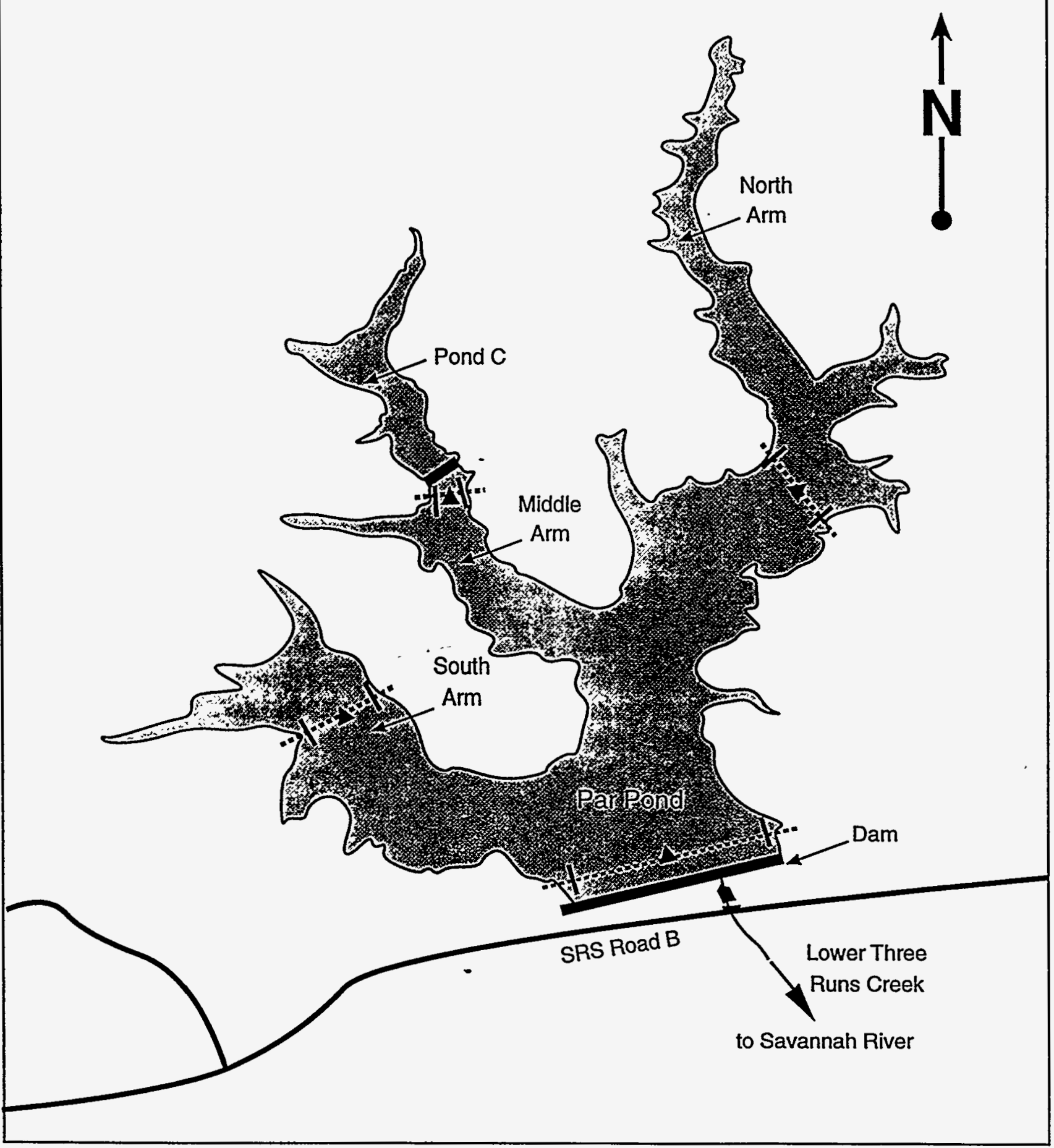

Figure 1. Map of the Par Pond system. Electrofishing transects are indicated by gold lines, sediment sampling transects by dashed lines, and water sampling points by triangles.

Sediment samples were collected in September Pond dam (one transect per arm; Figure 1). There 1995 at points along transects running across the north arm, middle arm, west arm, and near the Par were 9 to 12 sample points along each transect, depending on the width of the arm being sampled. 
The sample points were spaced somewhat more closely near the ends of the transects and further apart where the transects crossed deeper water to ensure that recently dry shallow areas reinundated by the refill were adequately sampled. Samples were collected from approximately the upper 10 centimeters ( 4 inches) of substrate with a ponar dredge. Sediment samples were placed in previously prepared bottles containing appropriate preservatives and placed on ice for shipment to analytical laboratories where they were analyzed for total mercury and gamma emissions (gammapulse-height analysis).

\section{Data analysis}

Differences in fish community structure among time periods were assessed on the basis of species number, total number of fish caught, and species rank abundance. Differences in species number and number of fish caught were compared among time periods with the T-method for unplanned comparisons (Sokal and Rohlf 1981). This procedure controlled the experiment-wise error rate (i.e., the error rate for the entire series of tests) and permitted the plotting of "comparison intervals" around each mean. Means whose comparison intervals did not overlap were significantly different at $\mathrm{P} \leq$ (less than or equal to) 0.05 . There were four replicates for each time period corresponding to (the number of species or the number of individual fish collected from) each of the four arms of Par Pond (total sample size was 24 [6 time periods and 4 sample areas]). For the pre-drawdown period, which was represented by numerous samples over time, an average value for each arm was calculated from the data. Both numbers of species and numbers of individuals were $\log _{10}(X+1)$-transformed for analysis to reduce heterogeneity of variance (Sokal and Rohlf 1981).

Correlations of species rank abundances among sample periods were assessed with the Spearman rank correlation coefficient (Sokal and Rohlf 1981). The correlations were treated as ordinary product-moment correlation coefficients for statistical testing (Sokal and Rohlf 1981). Because the same data were tested several times, the Bonferroni procedure (Marasciulo and McSweeney 1977) was used to maintain the probability value at the nominal level of 0.05 for the entire set of comparisons. Species collected in trivial numbers (i.e., less than $0.1 \%$ of the entire collection) were not included in the analysis.

To determine if the size distributions of individual species changed as a result of the drawdown, each species was divided into three total length groups of approximately equal range. Differences in the number of individuals within each length group between the pre-drawdown and fall post-refill time periods.were tested with the chi-square test for contingency tables ( $Z$ ar 1984). The length groups were 0-199 millimeters ([mm] 0-8 inches), 200$399 \mathrm{~mm}$ (8-15 inches), and $\geq$ (greater than or equal to) $400 \mathrm{~mm}$ (15 inches) for largemouth bass; 0 $149 \mathrm{~mm}$ (0-6 inches), 150-299 mm (6-11.5 inches), and 300-449 mm (11.5-15.5 inches) for lake chubsuckers; and 0-99 $\mathrm{mm}$ (0-4 inches), 100-199 mm (4-8 inches), and 200-299 mm (811.5 inches) for bluegill. The significance level was $\mathrm{P} \leq 0.05$.

Regression analysis was used to assess the relationship between fish total length and body burdens of mercury (micrograms per kilogram $[\mu \mathrm{g} / \mathrm{kg}]$ ) and cesium-137 (picoCuries per gram [pCi/g]). Because the concentration distributions were skewed, the data were transformed to a $\log _{10}$ scale $\left(X^{\prime}=\log _{10}(X+1)\right)$ to preserve the assumption of normality for statistical testing.

Fulton's Condition Factor (K) (Bagenal 1978) was used to evaluate changes in the food intake and general health of largemouth bass, bluegill, and redbreast sunfish (Lepomis auritus) over time. High values of $\mathrm{K}$ indicate high food intake relative to metabolic requirements and generally good health (Bennett 1970). K was calculated as follows: 


$$
K=W / L^{3} \times 10^{4}
$$

where $\mathrm{W}=$ weight in $\mathrm{g}$

and $\mathrm{L}=$ length in $\mathrm{mm}$.

Condition factors must be used carefully when comparing fish of different sizes (Cone 1989) since such comparisons are likely to generate misleading results unless growth is isometric. To avoid this problem, fish of each species were divided into size groups based on total length, and $\mathrm{K}$ was calculated individually for each size group.

Regression analysis also was used to determine if variations in $\mathrm{K}$ were related to body burdens of total mercury and cesium-137. This question was tested in two ways. First, $\mathrm{K}$ was regressed on $\log _{10}$ transformed mercury and cesium- 137 concentrations in a multiple regression model. F-tests were used to assess the significance of each independent variable. The second approach was to add $\log _{10}$-transformed total mercury and cesium-137 concentrations to a length-weight regression model and determine if these variables accounted for a significant amount of variation in weight after the effect of length was taken into account. As is typical of length-weight regression models used in fisheries biology, both total length ( $\mathrm{mm}$ ) and weight $(\mathrm{g})$ were $\log _{10}$-transformed to linearize the relationship between them (Bagenal 1978). The significance of the amount of variation in weight accounted for by total mercury and cesium-137 concentrations was evaluated with F-tests.

Results of the Par Pond water and sediment analyses were presented as arithmetic means, geometric means, maxima, and percent of samples with the analyte in quantities above the detection limit. Geometric means were calculated by backtransforming the average value of the logtransformed (i.e., $X^{\prime}=\log _{10}(X+1)$ ) data (Sokal and Rohlf 1981). Geometric means were presented together with arithmetic means because environmental contaminant data is often logarithmically distributed (Gilbert 1987). Means were not calculated for analytes never found in concentrations above the detection limit.

All statistical analyses were calculated using SYSTAT (Wilkinson 1989) or JMP (SAS 1989) software.

\section{Results and Discussion}

\section{Par Pond fish communities}

Seventeen species of fish were collected from $\mathrm{Par}$ Pond during the pre-drawdown period (Table 2). The most abundant by number were brook silverside $(50.7 \%)$, followed by bluegill (17.9\%) and largemouth bass (15.6\%). Other species collected in substantial numbers were lake chubsucker, coastal shiner (Notropis petersoni), golden shiner (Notemigonus crysoluecas), chain pickerel (Esox niger), yellow perch (Perca flavescens), redbreast sunfish, black crappie (Pomoxis nigromaculatus), and warmouth (L. gulosus).

The pre-drawdown samples can be compared with earlier samples collected with cove rotenone techniques during 1969, 1972 (Clugston 1973), 1977 (Hogan 1978), and 1980 (Martin 1980) (Table 3). Such comparisons must be approached cautiously because of method-specific biases (Nielson and Johnson 1983) and because the cove rotenone results were reported as weights rather than numbers. However, the cove rotenone studies consistently demonstrated that the most abundant species then in Par Pond were bluegill, lake chubsucker, largemouth bass, chain pickerel and "other sunfishes," all of which also were well represented in the pre-drawdown samples. Brook silverside and other small species were not prominent in the cove rotenone samples because of their comparatively insignificant weight." Within the limitations previously discussed, these comparisons indicate that the Par Pond fish assemblage was relatively stable from 1969-1985; most species were persistent and the same species gener- 
Table 2. Species relative abundances (percent by number) in Par Pond before and after the drawdown. Very rare species $(<0.1 \%)$ are not shown.

\begin{tabular}{|c|c|c|c|c|c|c|}
\hline Species ${ }^{a}$ & $\begin{array}{l}\text { Pre- } \\
\text { drawdown }\end{array}$ & $\begin{array}{l}\text { Drawdown } \\
1991 \\
\end{array}$ & $\begin{array}{l}\text { Drawdown } \\
1992 \\
\end{array}$ & Refill I & $\begin{array}{l}\text { Spring } \\
\text { post-refill }\end{array}$ & $\begin{array}{l}\text { Fall } \\
\text { post-refill }\end{array}$ \\
\hline \multicolumn{7}{|l|}{ औ } \\
\hline Brook silverside & 50.7 & 3.3 & 2.8 & 90.8 & 9.1 & 21.7 \\
\hline Bluegill & 17.9 & 46.7 & 45.8 & 2.8 & 21.4 & 17.9 \\
\hline Largemouth bass & 15.6 & 16.7 & 22.2 & 2.8 & 20.6 & 8.3 \\
\hline Lake chubsucker & 6.1 & 2.5 & 1.4 & 1.6 & 5.8 & 4.7 \\
\hline Coastal shiner & 3.4 & & 11.1 & & 9.7 & 4.8 \\
\hline Golden shiner & 1.8 & 3.3 & & 0.2 & 14.8 & 13.2 \\
\hline Chain pickerel & 1.3 & 5.0 & 1.4 & 1.6 & 2.9 & 4.5 \\
\hline Yellow perch & 0.9 & & & & 7.6 & 6.0 \\
\hline $\begin{array}{l}\text { Red breast } \\
\text { sunfish }\end{array}$ & 0.7 & 1.7 & & & 0.8 & 0.6 \\
\hline Black crappie & 0.4 & 0.8 & 1.4 & 0.2 & 0.4 & 1.4 \\
\hline Warmouth & 0.4 & 2.5 & - & & 0.2 & 1.9 \\
\hline Bowfin & 0.2 & 0.8 & 1.4 & & 0.8 & 0.4 \\
\hline Spotted sunfish & 0.1 & 0.8 & & & 1.2 & 2.0 \\
\hline Yellow bullhead & 0.1 & & & & & \\
\hline Dollar sunfish & 0.1 & & & & 4.7 & 1.2 \\
\hline Blueback herring & 0.1 & 14.2 & 12.5 & & & 11.0 \\
\hline Gizzard shad & 0.1 & & & & & 0.1 \\
\hline Mosquitofish & & & & & & 0.1 \\
\hline Swamp darter & & & & & & 0.1 \\
\hline
\end{tabular}

a Scientific names are provided in Appendix A.

ally shared numerical dominance. The community probably remained stable until the 1991 drawdown.

The drawdown resulted in a 50\% reduction in reservoir surface area, a 65\% reduction in reservoir volume (DOE 1994), and the loss of virtually all emergent and submerged vegetation from the original littoral zone (Mackey 1996). Water quality declined but generally remained acceptable for warm water fishes (Koch et al. 1996a). The average number of species collected from Par Pond declined significantly during the first year of the drawdown (1991) and decreased still further during the second year (1992) (Figure 2). The number of individual fish declined even more, reaching levels approximately an order of magnitude lower than before the drawdown (Figure 2).
Samples collected during the refill (January 1995) indicated slight increases in number of species and number of individuals, but both variables remained significantly lower than before the drawdown (Figure 2). However, samples collected in May and June 1995 (spring post-refill), approximately two to three months after refill was completed, indicated significant increases to pre-drawdown levels for both species number and number of individuals. The fall post-refill sample indicated additional increases in both species number and number of fish, although neither was significantly greater than during the spring post-refill sample.

Species rank abundances during the drawdown were significantly $(\mathrm{P} \leq 0.05)$ correlated with species rank abundances before the drawdown, reflect- 
Table 3. Percent composition by weight of fishes collected from Par Pond by cove rotenone sampling.

\begin{tabular}{|c|c|c|c|c|}
\hline Taxa & $1969^{a}$ & $1972^{a}$ & $1977^{b}$ & $1980^{\circ}$ \\
\hline & & & & \\
\hline Blueback herring & 0.1 & 0 & 0 & 0.1 \\
\hline Bluegill & 25.3 & 13.7 & 25.1 & 30.5 \\
\hline Other sunfishes & 13.1 & 13.7 & 10.8 & 15 \\
\hline Bullheads & 0.8 & 2.3 & 2.4 & 0.5 \\
\hline Bowfin & 2.5 & 1.8 & 2.7 & 0.4 \\
\hline Chain pickerel & 4.5 & 12.9 & 7.5 & 5.4 \\
\hline Crappie & 2.6 & 1.7 & 1.1 & 2.5 \\
\hline Lake chubsucker & 15.4 & 42.3 & 33.8 & 19.7 \\
\hline Other suckers & 2.2 & 0 & 0 & 0 \\
\hline Golden shiner & 0.4 & 5.2 & 5 & 7.3 \\
\hline Largemouth bass & 22.8 & 5.6 & 8 & 17.4 \\
\hline Yellow perch & 5.8 & 0.9 & 3.4 & 1.2 \\
\hline Miscellaneous & 4.6 & 0 & 0.2 & 0.4 \\
\hline
\end{tabular}

a Clugston (1973).

b Hogan (1978).

c Martin (1980).

ing the persistence of species such as bluegill and largemouth bass (Tables 4 and 2). Although significant, these correlations were moderate (i.e., 0.59 and 0.60; Table 4) because of marked decreases in brook silverside and lake chubsucker and increases in blueback herring (Alosa aestivalis) during the drawdown. Correlations with pre-drawdown samples increased during ( $\mathrm{r}=0.79)$ and following the refill ( $r=0.88$ and 0.75 ), reflecting increased abundance of brook silverside and lake chubsucker. Correlations of the magnitude of those demonstrated between the pre-drawdown and post-refill samples may be typical of interannual comparisons even in the absence of disturbances. Although major disturbances to the Par Pond system did not occur between the cove rotenone samples discussed above, the rank correlations amang them (0.600.95 , average of 0.81 ) were similar to the correlations between the pre-drawdown and post-refill electrofishing samples. Such variability may be attributable to sampling imprecision and interannual variations in the reproductive success of individual species.

Brook silverside and lake chubsucker, species that declined during the drawdown, typically prefer littoral zone habitats with extensive aquatic vegetation (Pflieger 1975; Robinson and Buchanan 1988). Other less abundant species that have similar habitat requirements and whose numbers decreased during the drawdown and subsequently increased following refill included yellow perch, dollar sunfish (L. marginatus), and spotted sunfish ( $L$. punctatus). Changes in the abundance of these species may be explainable on the basis of changes in the littoral zone habitat that resulted from the drawdown. Prior to the drawdown, Par.Pond supported a well-developed littoral zone with abundant aquatic vegetation. All the aquatic plant beds were eliminated by the drawdown, resulting in a new littoral area initially devoid of shelter, although aquatic vegetation was becoming established at the 

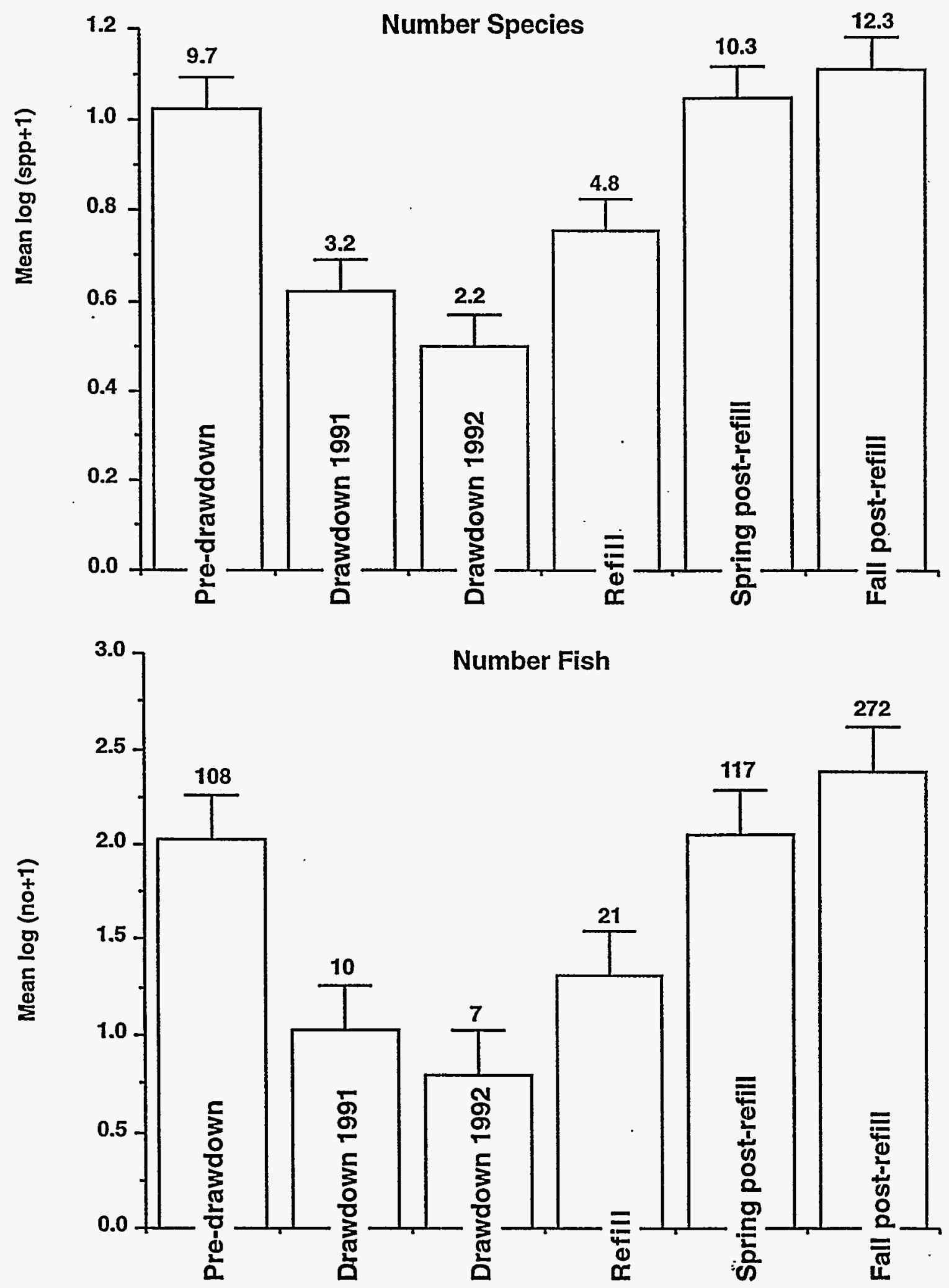

Figure 2. Average $\log _{10}$-transformed number of fish species (top figure) and number of fish (bottom figure) during sample periods in Par Pond. Means with comparison intervals that do not overlap are significantly different $(P \leq 0.05)$. Numbers above comparison interval bars are arithmetic averages. 
Table 4. Spearman correlation coefficients between fish species ranks before the drawdown of Par Pond, during the drawdown, and after Par Pond was refilled.

\begin{tabular}{|c|c|c|}
\hline Time periods & $r_{s}$ & $t$ \\
\hline & & \\
\hline Pre-drawdown vs. drawdown 1991 & 0.60 & $3.07^{*}$ \\
\hline Pre-drawdown vs .drawdown 1992 & 0.59 & $2.99^{*}$ \\
\hline Pre-drawdown vs. refill & 0.79 & $5.22^{*}$ \\
\hline Pre-drawdown vs. spring post-refill & 0.88 & $7.45^{\star}$ \\
\hline Pre-drawdown vs. fall post-refill & 0.75 & $4.72^{*}$ \\
\hline
\end{tabular}

* Significant at an experiment-wise error rate of $\mathrm{P} \leq 0.05$.

55-meter (181-foot) elevation by 1992 . During refill, the rapid rise in water level again resulted in littoral habitats without aquatic vegetation, but fish in shallow areas were afforded shelter by dense stands of submerged terrestrial vegetation (including pine trees up to 10 feet tall). After the refill, littoral zone vegetation was rapidly reestablished on the newly inundated sediments. The average percent cover of aquatic macrophytes at $46 \mathrm{Par}$ Pond transects during late 1995 was $45 \%$, compared with $65-70 \%$ before the drawdown, although the relative abundance of macrophyte species had changed; maidencane (Panicum hemitomon) was more prominent and cattail (Typha spp.) was less prominent than before drawdown (Mackey 1996). Thus, considerable littoral zone structure was available in 1995 to provide spawning substrate for phytophilous species (e.g., yellow perch) and cover for juvenile fishes. In addition to affecting community structure, the drawdown affected the size structure (i.e., distribution of length classes) within species. Analysis of the length frequencies of largemouth bass and lake chubsuckers (Figures 3 and 4) indicated that few small individuals remained at the end of the drawdown (as reflected in lengthfrequency distributions measured in January 1995 [refill]). Analysis of length-frequency distributions for bluegill (Figure 5) indicated a"generally similar, but less pronounced, trend. Length-frequency distributions would differ seasonally as a result of the recruitment of young-of-the-year fishes to catchable size; however, it is unlikely that seasonal factors were solely responsible for changes in size structure noted between pre-drawdown and refill samples. In the case of both largemouth bass and lake chubsucker, size groups up to $249 \mathrm{~mm}$ (10 inches) for largemouth bass and $299 \mathrm{~mm}$ (11.5 inches) for lake chubsuckers were largely absent in the January 1995 sample, suggesting that recruitment of young had been poor for at least the two previous years.

While post-drawdown community composition (reflected in species richness, species abundance, and rank abundance) rapidly came to resemble predrawdown community composition, the size structure within species remained quite different between pre- and post-drawdown samples. Pre-drawdown largemouth bass and lake chubsucker size structures were dominated by large individuals. In contrast, the post-drawdown size structures of both species were dominated by small individuals, reflecting highly successful reproduction of both species following refill. Young-of-the-year were prominently represented in the spring post-refill collection as indicated by the abundance of individuals in the $0-49-\mathrm{mm}$ (0-2-inch) size class. Many more juvenile fishes were observed than collected in the spring post-refill sample because they were too small to be retained by the nets. By the fall post-refill sample, these young-of-the-year fish had grown considerably as indicated by a reduction in the $0-49-\mathrm{mm}$ (0-2-inch) size class and an increase in the 50-99-mm (2-4-inch) size class. However 

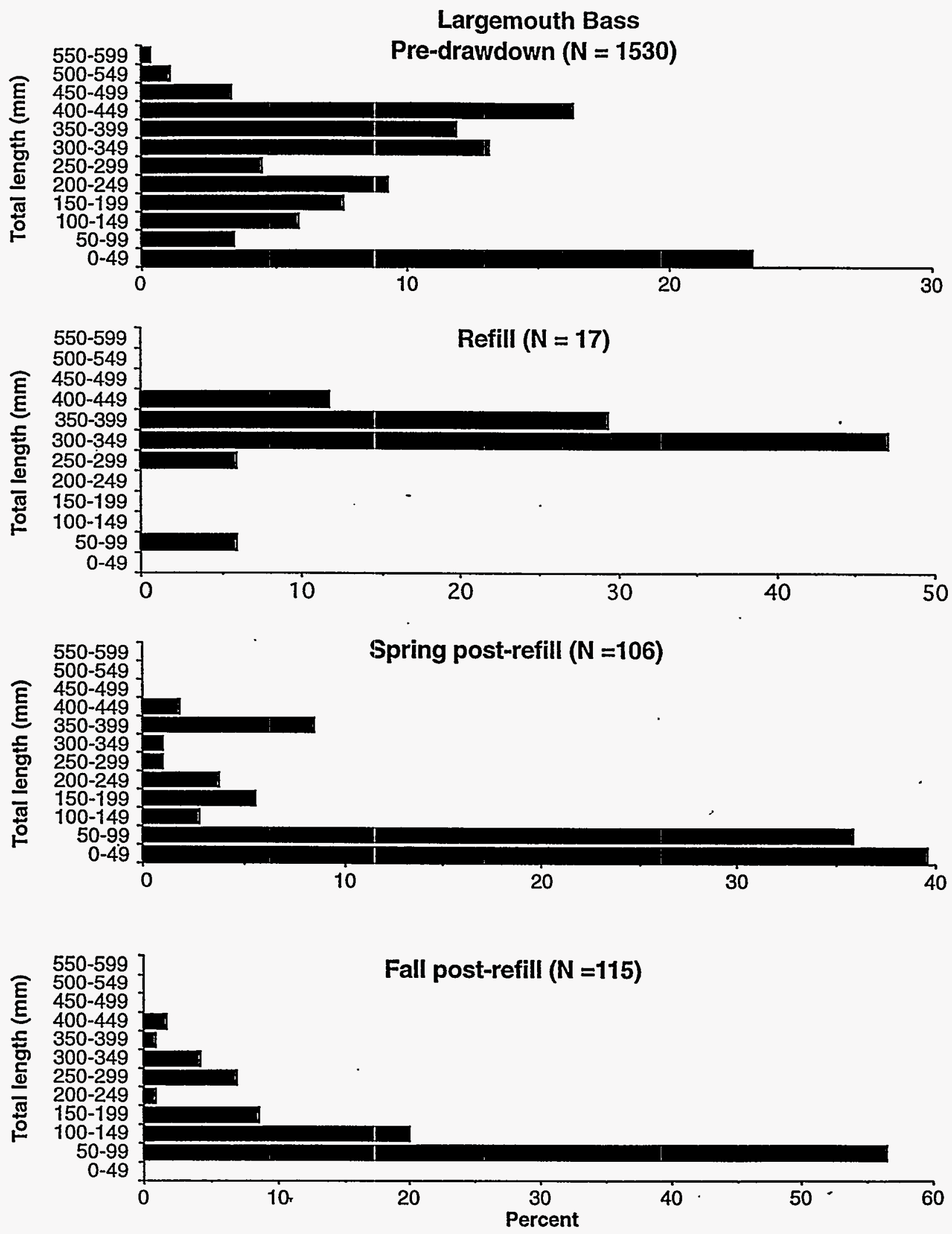

Figure 3. Length frequency distributions of largemouth bass in Par Pond during pre-drawdown (January 1984-January 1985), refill (January 1985), spring post-refill (May and June 1995), and fall post-refill (September and October 1995). 
Par Pond Fish, Water, and Sediment Chemistry

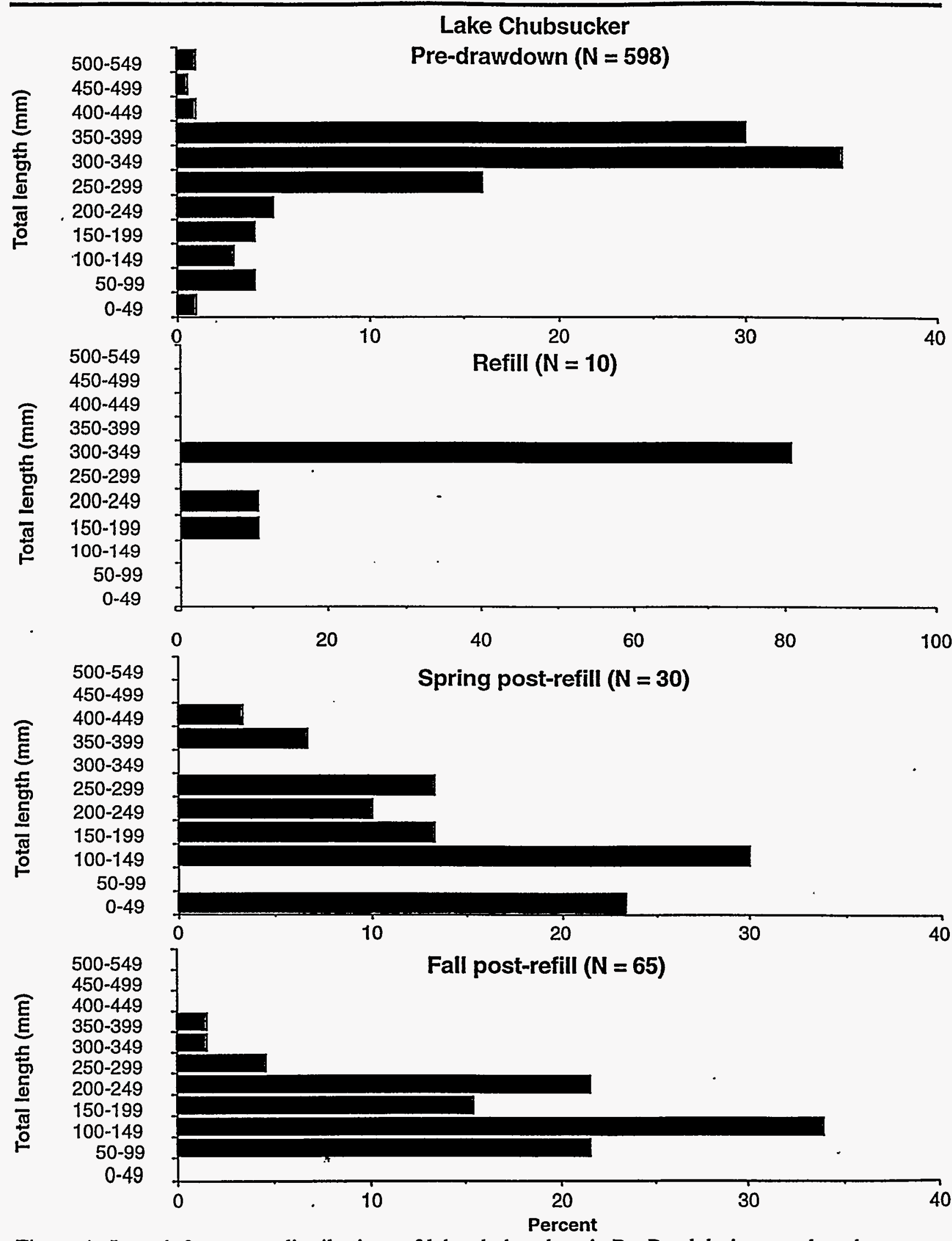

Figure 4. Length frequency distributions of lake chubsuckers in Par Pond during pre-drawdown (January 1984-January 1985), refill (January 1985), spring post-refill (May and June 1995), and fall post-refill (September and October 1995). 
Par Pond Fish, Water, and Sediment Chemistry

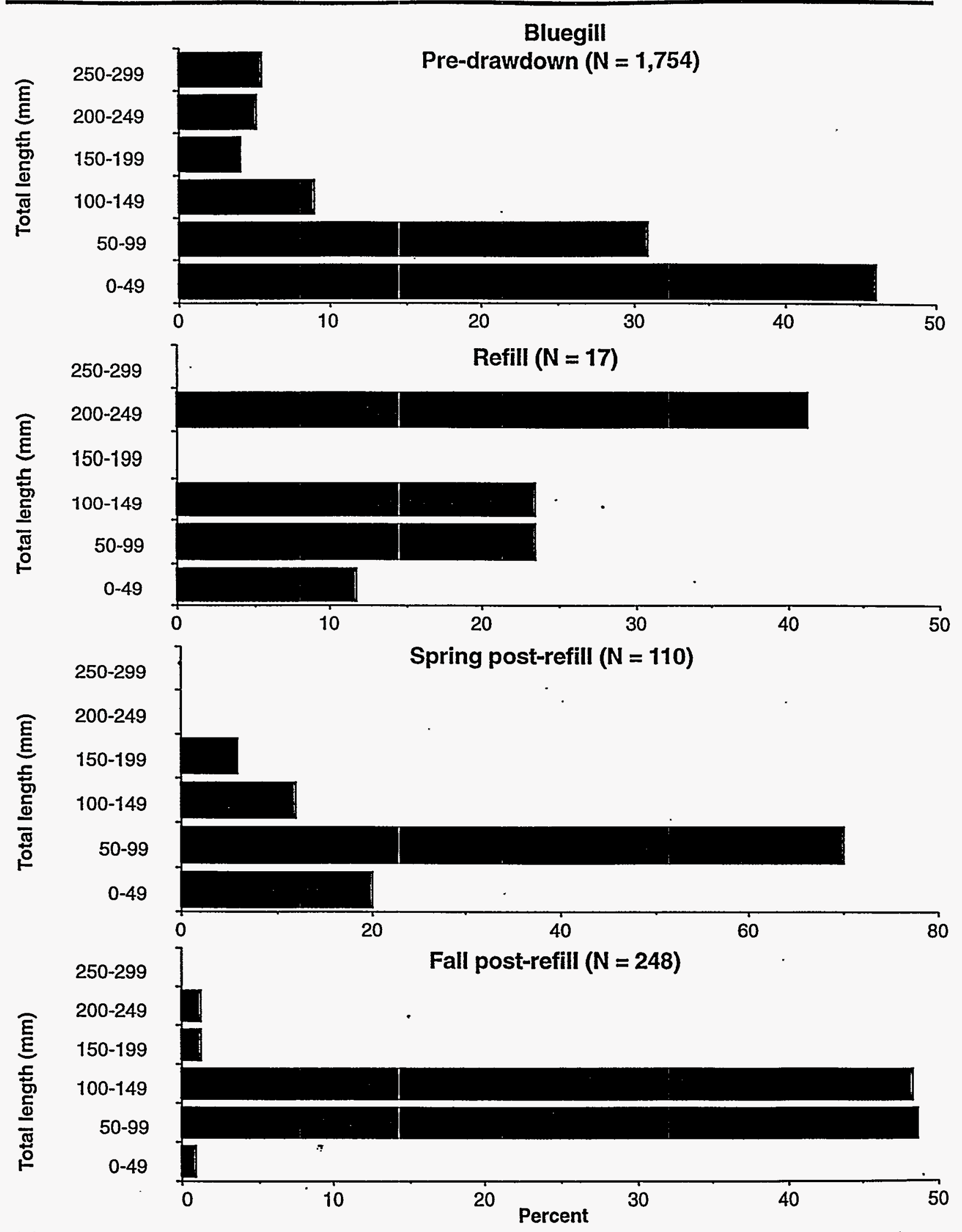

Figure 5. Length frequency distributions of lake chubsuckers in Par Pond during pre-drawdown (January 1984-January 1985), refill (January 1985), spring post-refill (May and June 1995), and fall post-refill (September and October 1995). 
the size distributions of both species in late 1995 still remained significantly different $(\mathrm{P} \leq 0.05)$ from the pre-drawdown size distributions. Bluegill exhibited a generally similar pattern to largemouth bass and lake chubsuckers except that the dates of the spring 1995 sample collection did not coincide with the period of maximum abundance of 0-49$\mathrm{mm}(0-2$-inch) juveniles. However, the prominence of the 50-99-mm (2-4-inch) size class in the fall 1995 sample collection indicates that bluegill also exhibited strong reproductive success following the refill. Like largemouth bass and lake chubsuckers, the size distribution of bluegill after the drawdown was significantly different from that before drawdown $(\mathrm{P} \leq 0.05)$.

The preceding data indicate that the Par Pond drawdown severely disturbed the Par Pond fish community, resulting in marked reductions in the number of species and abundance, particularly of those species dependent upon littoral zone vegetation. The size structure of individual species also was affected. That these changes were a consequence of the drawdown is suggested by the fact that sampling prior to the drawdown showed the Par Pond fish community to be temporally stable in terms of species' persistence and the general ranking of species' abundances (i.e., the same basic group of species numerically dominated the community although shifts in the relative ranking of these species were not uncommon). The effects of the drawdown on the Par Pond fish community were apparently the result of marked reductions in habitat size and changes in habitat quality, including the temporary loss of the littoral zone and its associated vegetation.

Fish community structure in Par Pond rapidly recovered following refill, indicating that it is resilient to disturbances resulting from changes in water level. In this respect the Par Pond fish community resembles stream fish communities, which have been shown to recover relatively quickly from perturbations of even a relatively extreme nature such as catastrophic flooding (Matthews 1986), severe drought (Bayley and Osborne 1993), and experimental defaunation (Meffe and Sheldon 1990). Recovery of the Par Pond fish community apparently was due to recolonization by species reduced in or temporarily eliminated from the main body of the reservoir. These species experienced highly successful reproduction following refill, which resulted in the repopulation of Par Pond with large numbers of juvenile fishes. The final result was a rapid return to species richness and rankings similar to pre-drawdown conditions, although the size structures of individual species significantly differed from pre-drawdown size structures. An important source for species that were largely eliminated from the main body of Par Pond to repopulate the reservoir may have been comparatively small refugia located in the headwater stream that feeds Par Pond (Figure 1) and possibly in shallow coves where the regrowth of some aquatic vegetation provided small species (e.g., dollar sunfish, yellow perch, and coastal shiner) with shelter from predaceous fish and birds.

It is likely that both immigration and reproduction contributed to the recovery of the Par Pond fish community with the influence of reproduction more evident. However, a "seed pool" for recolonization is clearly essential, thus underscoring the importance of refugia where some individuals can persist during a perturbation. The number of individuals sustained in refugia probably does not need to be large given the biotic potential of most fishes (Nikolsky 1963). The other requirement for successful expansion of recolonizing species is the presence of a suitable habitat for them and their early life stages. Such habitat was provided in Par Pond first by inundated terrestrial vegetation and subsequently by the rapid regrowth of aquatic vegetation between the drawdown shoreline at the 55-meter (181-foot)-elevation and the restored 61-meter (200-foot)-elevation shoreline, both of which presumably provided shelter from predators and spawning substrate for phytophilous species. Observations during sampling indicated that young-of-the-year fishes aggregated near such 
shelter. The importance of habitat in determining the structure of recolonizing fish assemblages also has been noted for stream fish communities (Meffe and Sheldon 1990).

While species composition and richness rapidly returned to pre-drawdown levels once Par Pond refilled, the size structure of individual species was significantly different than before the drawdown. Pre-drawdown size structures of largemouth bass and lake chubsucker were generally characteristic of established and relatively stable populations with a preponderance of large individuals. Substantial numbers of large bluegill were also present, although this species was strongly represented by juveniles as well. Post-drawdown species size structures were the reverse of those pre-drawdown, with a preponderance of juveniles and relatively few large fish. Such size structures are characteristic of expanding populations (Rickelefs 1982) and are the result of highly successful reproduction in the restored habitat. Given their probable growth rate (Carlander 1969, 1977) it is likely that the size distributions of largemouth bass and other comparatively long-lived fishes will require at least several years to return to their pre-drawdown structure.

To the extent that Par Pond is representative of other southeastern reservoirs, the results of this study suggest that southeastern reservoir fish communities are highly resilient to extensive and relatively long-term reductions of habitat volume and to the destruction of littoral zone habitat. Reservoir fishes may be resilient to such impacts because of their long evolution in lotic and lentic systems that naturally experience changes in water level as a result of intra- and interannual variations in rainfall. They may be less resilient to impacts that do not mimic natural environmental perturbations, such as the presence of toxic materials. Further, a major perturbation, such as a drawdown, could affect the balance between closely competing species and result in subsequent shifts in species composition from the pre-disturbance state. The increase in blueback herring abundance in Par Pond following the drawdown may be an example of this, although more time will be needed to assess the permanence of this change. Lastly, rapid restoration of the littoral zone habitat through the regrowth of aquatic vegetation undoubtedly contributed to the recovery of the Par Pond fish community. Factors that interfere with the natural recovery of littoral zone habitat, such as vegetation control programs, might result in slower or incomplete restoration of the fish community.

\section{Condition factors}

Past studies have indicated that largemouth bass from Par Pond were characterized by unusually low condition factors (K) (Paller and Saul 1985). This was attributed to increased metabolic rates among Par Pond bass due to elevated temperatures resulting from the discharge of heated cooling water into Par Pond (Gibbons et al. 1978). Conversely, it also was hypothesized that the low condition factors were primarily the result of inadequate forage with elevated temperatures, perhaps playing a secondary role (Paller and Saul 1985). A comparison of pre-drawdown largemouth bass condition factors with fall post-refill condition factors indicated that both were quite similar and lower than is typical for most reservoirs (Table 5). Reasons for low condition in late 1995, approximately seven years after the cessation of reactor operations, are unclear. Substantial amounts of forage-sized fish (blueback herring and young-of-the-year of a number of species) were present in Par Pond in 1995, suggesting that adult bass should have had adequate food supplies, although relatively dense regrowths of aquatic vegetation and the inundated terrestrial vegetation may have reduced the success of predators by providing smaller fish with shelter. The average condition factor of Par Pond bluegill in fall post-refill samples was 1.64 , only slightly lower than the pre-drawdown condition (1.72). Comparative data for other species are unavailable. 
Table 5. Condition (K) of largemouth bass in Par Pond before drawdown and after the refill.

\begin{tabular}{|c|c|c|c|c|c|}
\hline \multirow[b]{2}{*}{$\begin{array}{c}\text { Total length } \\
(\mathrm{mm})\end{array}$} & \multicolumn{2}{|c|}{ Pre-drawdown } & \multicolumn{3}{|c|}{ Fall post-refill } \\
\hline & $\mathbf{K}$ & Number & $K$ & $\begin{array}{l}\text { Standard } \\
\text { error }\end{array}$ & Number \\
\hline n & $\because \because$ & \% & 6 & $6 \%$ & $6 \%$ \\
\hline $100-200$ & 1.08 & 275 & 1.13 & 0.023 & 10 \\
\hline $201-300$ & 1.16 & 342 & 1.16 & 0.026 & 17 \\
\hline $301-400$ & 1.21 & 656 & 1.27 & 0.024 & 17 \\
\hline$>400$ & 1.12 & 581 & 1.12 & 0.104 & $8^{*}$ \\
\hline
\end{tabular}

* Significant at an experiment-wise error rate of $\mathrm{P} \leq 0.05$.

\section{Contaminants in Par Pond fish}

The geometric mean total mercury concentration in Par Pond largemouth bass (whole fish) was 581 $\mu \mathrm{g} / \mathrm{kg}$ (Table 6). These concentrations were greater than in L-Lake largemouth bass $(351 \mu \mathrm{g} / \mathrm{kg})$. Total mercury concentrations in Par Pond largemouth bass increased significantly $(\mathrm{P} \leq 0.001)$ with fish size (Figure 6), reflecting bioaccumulation in older fish. Mercury contamination is common among fish taken from SRS water bodies that receive inputs of Savannah River water (Newman and Messier 1994). It is likely that much of this mercury originates offsite as suggested by mercury concentrations in largemouth bass collected from the Savannah River during 1992-1994 (geometric mean of $557 \mu \mathrm{g} / \mathrm{kg}$; Westinghouse Savannah River Company Environmental Monitoring Section [EMS], unpublished data), which were approximately the same as mercury concentrations in Par Pond largemouth bass (Table 6).

The geometric mean mercury concentrations in bluegill and lake chubsucker from Par Pond averaged 154 and $133 \mu \mathrm{g} / \mathrm{kg}$, respectively (Table 6), substantially lower than in Par Pond largemouth bass. Because mercury bioaccumulates in aquatic food chains, concentrations are typically higher in top predators (such as largemouth bass) than in species that feed at lower trophic levels (such as bluegill and lake chubsuckers) (Rowan and Rasmussen 1994).
Mercury body burdens in fish often increase when a reservoir is initially filled because of an increase in methylation as a result of greater microbial activity. There was concern that similar increases could occur in Par Pond after the reservoir was refilled following its extended drawdown. Jagoe. et al. (1994) observed that mercury concentrations in largemouth bass ranged from approximately $50-$ $1900 \mu \mathrm{g} / \mathrm{kg}(\mathrm{n}=300)$ just before the drawdown, during the drawdown, and after the drawdown was completed (1991-1993). Samples taken by EMS when Par Pond was drawn down (1992-1994) indicated that mercury concentrations in largemouth bass ranged from $170-2730 \mu \mathrm{g} / \mathrm{kg}$ with a geometric mean of $1293 \mu \mathrm{g} / \mathrm{kg}(\mathrm{n}=16)$. These values can be compared with the fall post-refill (September 1995) geometric mean mercury concentration of $581 \mu \mathrm{g} / \mathrm{kg}$ in largemouth bass (maximum of $3180 \mu \mathrm{g} / \mathrm{kg}$; Table 6). This comparison indicates that as of September 1995 (approximately six months after refill was completed), there was little evidence of increased mercury body burdens in Par Pond largemouth bass. Continued monitoring will determine if increases occur in the future.

The geometric mean cesium-137 concentration in Par Pond largemouth bass (whole fish) was 4.61 $\mathrm{pCi} / \mathrm{g}$ (Table 6), nearly an order of magnitude higher than in L-Lake largemouth bass $(0.62 \mathrm{pCi} / \mathrm{g}$; Paller 1996). Body burdens of cesium-137 increased significantly ( $P \leq 0.001$ ) with fish size (Figure 7), in 
Table 6. Average total mercury $(\mu \mathrm{g} / \mathrm{kg})$ and cesium-137 (pCi/g) body burdens in fishes collected from Par Pond. October 1995.

\begin{tabular}{|c|c|c|c|c|c|c|}
\hline Species & Number & $\begin{array}{l}\text { Mean total } \\
\text { length } \\
\text { (mm) }\end{array}$ & $\begin{array}{l}\text { Geometric } \\
\text { mean ( } 95 \% \\
\text { confidence } \\
\text { interval) }\end{array}$ & $\begin{array}{l}\text { Arithmetic } \\
\text { mean }\end{array}$ & Median & Maximum \\
\hline \multicolumn{7}{|c|}{ 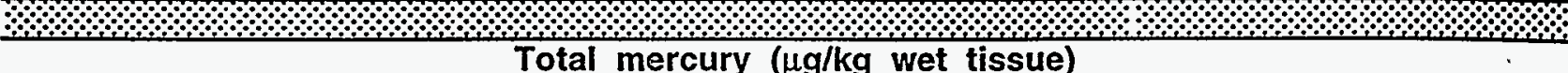 } \\
\hline $\begin{array}{l}\text { Largemouth } \\
\text { bass }\end{array}$ & $38^{a}$ & 347 & $\begin{array}{l}581 \\
(493-687)\end{array}$ & 673 & 576 & 3180 \\
\hline $\begin{array}{l}\text { Lake } \\
\text { chubsucker }\end{array}$ & $4^{\mathrm{a}}$ & 309 & $\begin{array}{l}133 \\
(108-164)\end{array}$ & 140 & 125 & $216 \because \because$ \\
\hline Bluegill & $14^{b}$ & 128 & $\begin{array}{l}154 \\
(136-175)\end{array}$ & 157 & 159 & 203 \\
\hline \multicolumn{7}{|c|}{ Cesium-137 (pCi/g wet tissue) } \\
\hline $\begin{array}{l}\text { Largemouth } \\
\text { bass }\end{array}$ & $38^{a}$ & 347 & $\begin{array}{l}4.61 \\
(4.11-5.15)\end{array}$ & 4.84 & 4.69 & 8.57 \\
\hline $\begin{array}{l}\text { Lake } \\
\text { chubsucker }\end{array}$ & $4^{a}$ & 309 & $\begin{array}{l}3.27 \\
(2.57-4.10)\end{array}$ & 3.41 & 3.73 & 4.38 \\
\hline Bluegill & $14^{b}$ & 128 & $\begin{array}{l}1.70 \\
(1.56-1.86)\end{array}$ & 1.71 & 1.62 & 2.29 \\
\hline
\end{tabular}

a Most samples consisted of individual fish, except for small specimens, which were composited.

b Most samples were composites of a number of individuals.

contrast to L Lake, where largemouth bass total length and cesium-137 concentration were unrelated (Paller 1996). Geometric mean cesium-137 concentrations in bluegill and lake chubsucker were 1.70 and $3.27 \mathrm{pCi} / \mathrm{g}$, respectively (Table 6). As with largemouth bass, bluegill from Par Pond were characterized by much higher cesium-137 body burdens than bluegill from L Lake (Paller 1996) (cesium-137 was not analyzed in lake chubsuckers in LLake). Greater cesium-137 body burdens in Par Pond fish probably reflect greater contamination of Par Pond with cesium-137 as a result of radionuclide releases from $P$ and $R$ Reactors. Other factors such as differences in fish age and trophic dynamics may also play a role. Cesium-137 concentrations in Par Pond largemouth bass were substantially higher than values reported in largemouth bass from, the uncontaminated Clarks Hill reservoir (Sugg et al. 1995) and higher than values recently reported for largemouth bass from the Savannah River (Jannik 1996).
Changes in the Par Pond water chemistry appeared to be responsible for increased levels of cesium137 in Par Pond bass during the early stages of the drawdown (Whicker et al. 1993a). However, cesium-137 levels in largemouth bass collected in the fall of 1995 (4.6 pCi/g wet weight [Table 6]) were somewhat lower than in 19 largemouth bass collected from Par Pond by Whicker (1991) just. before the start of the drawdown $(8.8 \mathrm{pCi} / \mathrm{g}$ wet weight). Although Whicker's measurements were from the muscle only, which is where cesium-137 accumulates, and the 1995 measurements were from whole fish, this comparison suggests that the increases were transient or at least had diminished in magnitude by late 1995.

Sugg et al. (1995) suggest that elevated levels of mercury and radiocesium are responsible for low condition and DNA damage among largemouth bass in SRS reservoirs. In the present study, largemouth bass condition factors were significantly $(\mathrm{P} \leq 0.05)$ related to tissue concentrations of total 


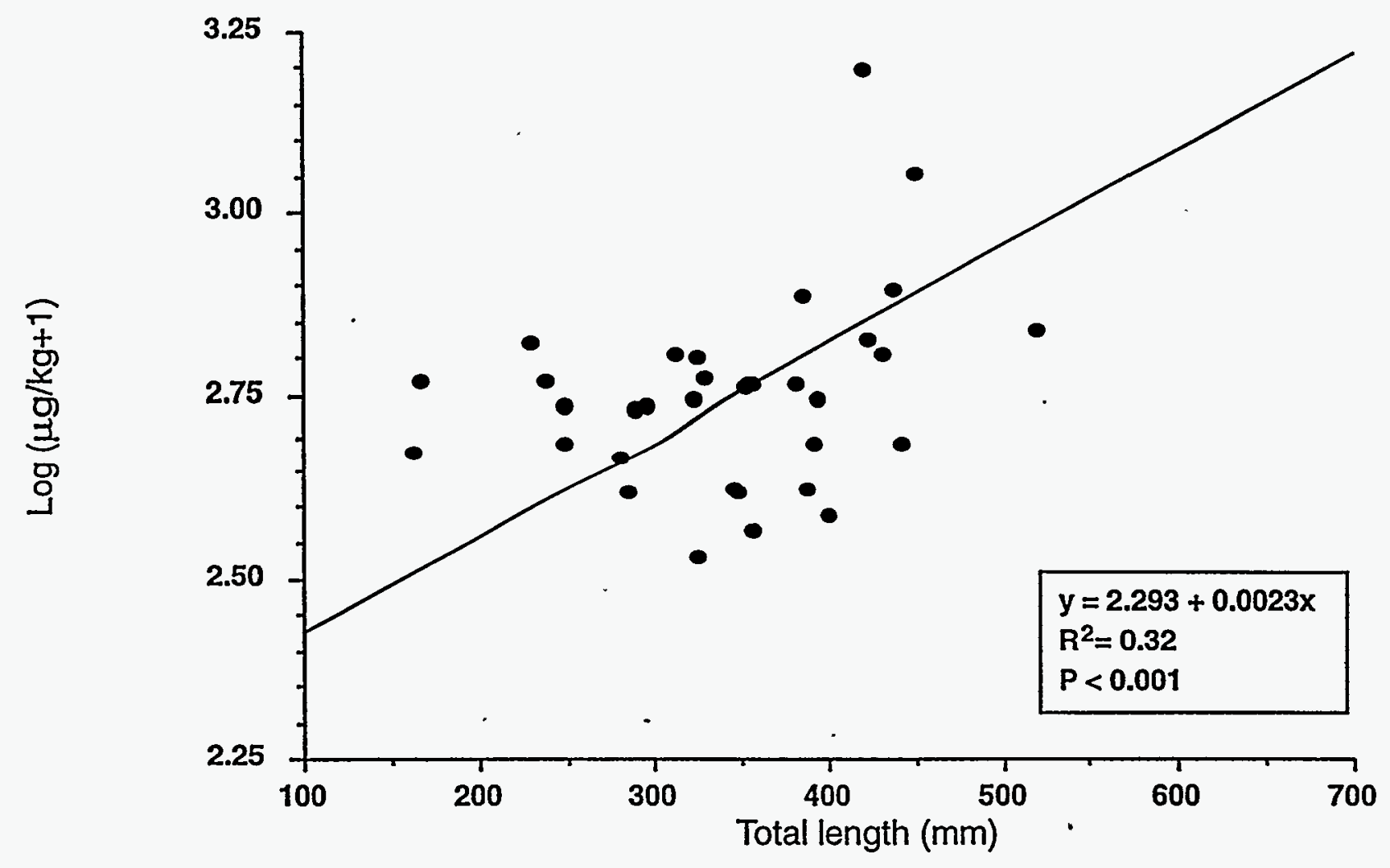

Figure 6. Regression of mercury concentration. $(\mu \mathrm{g} / \mathrm{kg}$ ) in largemouth bass of various sizes (total length in millimeters) collected from Par Pond. October 1995.

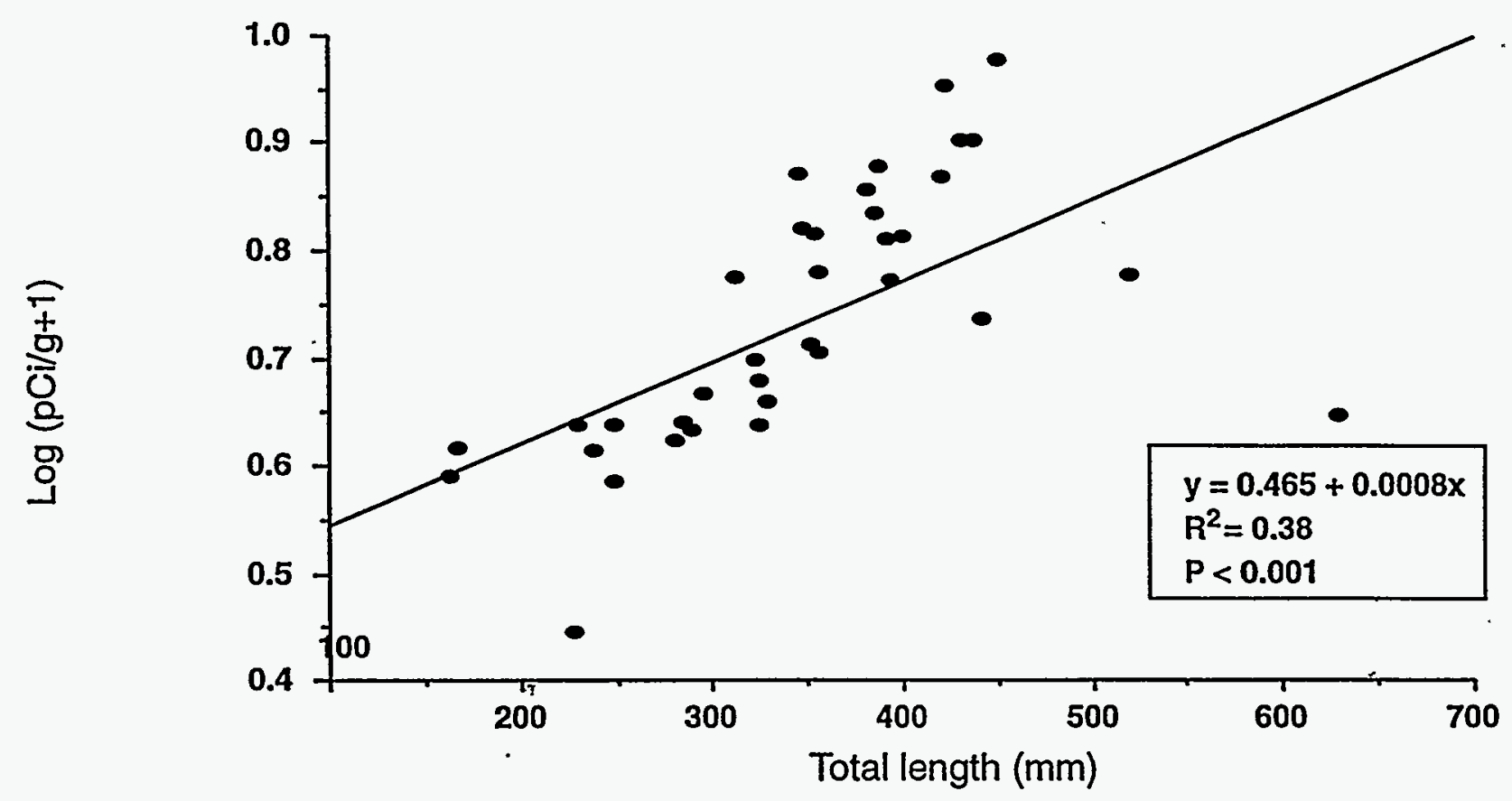

Figure 7. Regression of cesium-137 concentration (pCi/g) in largemouth bass of various sizes (total length in millimeters) collected from Par Pond. October 1995. 
mercury but not tissue concentrations of cesium137 (Table 7). The effects of total mercury and cesium-137 concentrations on fish weight also were evaluated by assessing the ability of these variables to add explanatory power to a length/ weight regression model for Par Pond largemouth bass (Table 7). Again, tissue concentrations of total mercury contributed significantly to the model, indicating that mercury was associated with variations in fish weight once length was taken into account. These results are different from those reported for L-Lake largemouth bass (Paller 1996) in that neither total mercury nor cesium-137 concentrations were related to the fishes' condition. Reasons for this difference are unclear, but may be related to higher levels of contamination in $\mathrm{Par}$ Pond. Similarly, it is uncertain whether high body burdens of mercury are directly responsible for low condition among Par Pond largemouth bass or whether the correlation between these variables results from other factors that have not yet been elucidated.

\section{Contaminants in Par Pond sediments and water}

Radionuclides have been detected in Par Pond sediments (Koch et al. 1996b). However, the radionuclide found in the highest concentration, and the most significant from the perspective of biological risk (Whicker et al. 1993b), is cesium-137. Prerefill surveys indicated that the average cesium137 concentration in Par Pond sediments was approximately $7 \mathrm{pCi} / \mathrm{g}$ (Winn 1991 cited in Hamby 1991) and that cesium-137 concentrations were higher in deeper portions of Par Pond (Winn 1991). Other pre-refill studies indicated that the distribution of cesium-137 was "patchy" over relatively small spatial scales (Paller and Wike 1996).

Fall post-refill measurements indicated that the arithmetic mean cesium-137 concentration in $\mathrm{Par}$ Pond sediments was approximately $9.0 \mathrm{pCi} / \mathrm{g}$ (Table 8) and that cesium-137 concentrations were variable, but highest in the deep water areas located relatively far from the post-refill shoreline
(Figure 8). These concentrations and spatial distribution patterns are similar to those reported before the refill and suggest that sediment movements and sediment chemistry changes associated with the refill have not substantially affected cesium137 concentrations or distributions within Par Pond.

Other gamma-emitting radionuclides present at detectable levels in Par. Pond sediments included actinium-228, cobalt-60, lead-212, potassium-40, and thorium-234 (Table 8). However, these constituents had much lower activities than cesium-137.

Mercury, a nonradioactive but potentially toxic metal, was present in detectable concentrations at $20 \%$ of the sample sites (Table 8 ). The average concentration, $39 \mu \mathrm{g} / \mathrm{kg}$, was below the EPA Region IV sediment screening value $(130 \mu \mathrm{g} / \mathrm{kg}$; EPA 1995). However, the highest mercury concentration, $323 \mu \mathrm{g} / \mathrm{kg}$, did exceed the EPA Region IV screening value for mercury in sediments. As with cesium-137, the highest mercury concentrations occurred in the deeper portions of Par Pond (Figure 9).

Several gamma-emitting radionuclides were detectable in water samples from Par Pond including cesium-137, potassium-40, thorium-234, and lead212 (Table 9). These radionuclides also occurred in the sediments (Table 8). Nonvolatile-beta-emitting radionuclides also were detected in most of the Par Pond water samples. Element-specific analyses were not conducted for beta-emitting radionuclides. None of the metals measured in Par Pond water samples exceeded EPARegion IV acute toxicity screening values for surface waters (EPA 1995). However, the detection limits for beryllium, cadmium, lead, mercury, and silver were not low enough to ensure that these metals were below the EPA Region IV surface water chronic toxicity screening values.

There was concern that the refill of Par Pond might cause contaminants in the sediments to become 
Table 7. Regressions of largemouth bass condition $(\mathrm{K})$ on total mercury $(\mu \mathrm{g} / \mathrm{kg})$ and cesium-137 (pCi/g). September 1995.

\begin{tabular}{|c|c|c|c|c|c|}
\hline Model & $\begin{array}{l}\text { Dependent } \\
\text { variable }\end{array}$ & $\begin{array}{l}\text { Independent } \\
\text { variable }\end{array}$ & F Ratio & Probability & Number \\
\hline $6 \beta$ & an & 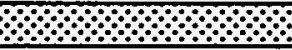 & m & m & $\ldots$ \\
\hline \multirow[t]{2}{*}{1} & $\mathrm{~K}$ & $\log _{10}$ mercury & 11.59 & 0.002 & 36 \\
\hline & & $\log _{10}$ cesium-137 & 0.01 & 0.952 & \\
\hline \multirow[t]{3}{*}{2} & $\log _{10}$ weight & $\log _{10}$ total length & 1168.83 & $<0.001$ & 36 \\
\hline & & $\log _{10}$ mercury & 17.47 & $<0.001$ & - \\
\hline & & $\log _{10}$ cesium-137 & 2.00 & 0.167 & \\
\hline
\end{tabular}

resuspended in the water column. Fall post-refill cesium-137 concentrations in Par Pond water averaged $4.9 \mathrm{pCi} / \mathrm{L}$ (Table 9 ), only slightly more than before the drawdown (3.5 pCi/L; Boni 1991), indicating little evidence of resuspension. The slight difference between these measurements could be seasonal, since cesium-137 concentrations in the Par Pond water vary seasonally (Alberts et al. 1979).

The cumulative impact of the contaminants in $\mathrm{Par}$ Pond water and sediments on the Par Pond fish community is not certain. Recent reports (Sugg et al. 1995) suggest that elevated mercury and cesium-137 levels in SRS reservoirs are associated with genetic damage to largemouth bass. However, Par Pond has supported a diverse, self-sustaining fish assemblage comparable to that in other southeastern reservoirs for many years (Paller and Saul 1985) despite the presence of these contaminants. Further, this community was resilient enough to recover quickly from the disruptive effects of the Par Pond drawdown. Lastly, a conservative ecological risk model recently was used to evaluate the effects of radiological contamination on Par Pond fish. The results indicated that dose levels in Par Pond were at least an order of magnitude lower than those documented as causing mortality (Hinton and Whicker, in press). In summary, current evidence suggests that contaminants in Par Pond may be responsible for individual effects such as genetic damage that could be manifested in relatively subtle population effects, but not in measur- able community level changes in species composition or species richness.

\section{Anticipated effects of fluctuating water levels on the Par.Pond fish community}

Shutdown of the Savannah River water distribution system could cause the water level of Par Pond to fluctuate by as much as several feet in response to seasonal changes in rainfall and evaporation. There is considerable literature showing that water level fluctuations can directly and indirectly affect fish communities. Direct effects occur as a result of changes in the area and volume of water, changes in the availability of spawning substrate and cover, alterations in the availability of food, and dewatering of eggs and larvae (Lantz et al. 1964; Estes 1972; Gaboury and Patalas 1984): Indirect effects can occur as a result of alterations in the type and quantity of littoral zone aquatic vegetation and water-level related changes in susceptibility to summer and winter kills (Gaboury and Patalas 1984). The magnitude of these effects and whether they are beneficial or deleterious largely depends on the extent and timing of the water level fluctuations.

Moderate decreases in water level during the fall and winter followed by increases in the spring generally have beneficial effects on fish populations. These benefits have been summarized by Liston and Chubb (1985) as follows: 
Table 8. Concentrations of gamma-emitting radionuclides ( $\mathrm{pCi} / \mathrm{g})$ and mercury $(\mu \mathrm{g} / \mathrm{kg})$ in Par Pond sediments. September 1995.

\begin{tabular}{|c|c|c|c|c|c|c|c|c|c|}
\hline Analyte $(\mathrm{pCi} / \mathrm{g})$ & $\begin{array}{l}\text { Average } \\
\text { detection } \\
\text { limit }\end{array}$ & $\begin{array}{l}\text { Percent } \\
\text { detects }\end{array}$ & $\begin{array}{l}\text { Arith. } \\
\text { mean }\end{array}$ & LCIb & $\mathrm{UCIC}$ & Maximum. & $\begin{array}{l}\text { Geo. } \\
\text { mean }\end{array}$ & $\mathrm{LCI}^{\mathrm{b}}$ & $\mathrm{UClc}$ \\
\hline \multicolumn{10}{|c|}{ hloblol } \\
\hline Actinium-228 & 0.03 & 100 & 1.16 & 1.05 & 1.27 & 1.97 & 1.14 & 0.45 & 2.14 \\
\hline Antimony-124 & 0.01 & 0 & & & & & & & \\
\hline Antimony-125 & 0.05 & 0 & & & & & & & \\
\hline Barium-133 & 0.02 & 0 & & & & & & & \\
\hline Cerium-144 & 0.09 & 0 & & & & & & & \\
\hline Cesium-134 & 0.01 & 0 & & & & & & & \\
\hline Cesium-137 & 0.01 & 100 & 9.01 & 2.36 & 15.66 & 124 & 3.17 & 1.5 & 5.95 \\
\hline Cobalt-57 & 0.01 & 0 & & & & & & & \\
\hline Cobalt-58 & 0.01 & 0 & & & & & & & \\
\hline Cobalt-60 & 0.01 & 40 & 0.06 & & & 1.13 & 0.05 & 0 & \\
\hline Europium-152 & 0.04 & 0 & - & & & & & & \\
\hline Europium-154 & 0.08 & 0 & & & & & & & \\
\hline Europium-155 & 0.05 & 9 & 0.03 & & & 0.13 & 0.02 & & \\
\hline Lead-212 & 0.02 & 100 & 1.2 & 1.08 & 1.32 & 2.04 & 1.19 & 0.48 & 2.23 \\
\hline Manganese-54 & 0.01 & 93 & 0.02 & 0.02 & 0.02 & 0.05 & 0.02 & 0 & 0.09 \\
\hline - Neptunium-239 & 0.08 & 18 & 0.05 & & & 0.23 & 0.05 & & \\
\hline Potassium-40 & 0.08 & 64 & 0.61 & 0.42 & 0.8 & 3.17 & 0.51 & 0.14 & 1.01 \\
\hline Promethium-144 & 0.01 & 0 & & & & - & & & \\
\hline Promethium-146 & 0.03 & 2 & 0.01 & & & 0.11 & 0.02 & & \\
\hline Ruthenium-106 & 0.12 & 0 & & & & & & & \\
\hline Sodium-22 & 0.01 & 0 & & & & & & & \\
\hline Thorium-234 & 0.54 & 62 & 0.81 & 0.67 & 0.95 & 1.7 & 0.74 & 0.25 & 1.42 \\
\hline Tin-113 & 0.02 & 0 & & & & & & & \\
\hline Yttrium-88 & 0.01 & 0 & & & & & & & \\
\hline Zinc-65 & 0.02 & 0 & & & & & & & \\
\hline Zirconium-95 & 0.02 & 2 & 0.01 & & & 0.04 & 0 & & \\
\hline Mercury $(\mu \mathrm{g} / \mathrm{kg})$ & 40.2 & 20 & 38.81 & & & 323.00 & 23.55 & & \\
\hline
\end{tabular}

a Sample size was 45 .

b Lower confidence limit was not calculated if fewer than $50 \%$ of the samples were below the detection limit.

c Upper confidence limit was not calculated if fewer than $50 \%$ of the samples were below the detection limit.

- the inundation of shoreline vegetation, which initiates its decomposition and subsequent release of nutrients;

- the addition of terrestrial food sources (e.g., in sects) to the water;

- the addition of shelter and spawning habitat for littoral zone species as terrestrial areas are flooded; and

- the creation of a new area of aquatic habitat that is sparsely populated with aquatic predators and competitors stimulates reproductive success and growth of fishes that repopulate the area. 
Table 9. Radionuclide and metal concentrations in Par Pond water. Samples were taken near the top and near the bottom. September 1995.

\begin{tabular}{|c|c|c|c|c|c|c|c|c|c|c|}
\hline Radioisotopes & Units & $\begin{array}{l}\text { Average } \\
\mathrm{DL}\end{array}$ & $\begin{array}{l}\text { Percent } \\
\text { detects }^{b}\end{array}$ & $\begin{array}{l}\text { Top } \\
\text { Arithmetic Seometric } \\
\text { mean Inean }\end{array}$ & Maximum & $\begin{array}{l}\text { Average } \\
\text { DLa }\end{array}$ & $\begin{array}{l}\text { Percent } \\
\text { detects }^{b}\end{array}$ & $\begin{array}{l}\text { Bottòm } \\
\text { Arithmetic } \\
\text { mean }\end{array}$ & $\begin{array}{l}\text { Geometric } \\
\text { Inean }\end{array}$ & Maximum \\
\hline 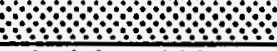 & & $6 \%$ & & & & & 0 & $\because 69$ & & \\
\hline Actinium-228 & $\mathrm{pCi} / \mathrm{l}$ & 10.41 & 0 & & & 10.34 & & & & \\
\hline Antimony-124 & $\mathrm{pCi} / \mathrm{l}$ & 2.80 & 0 & & & 2.66 & 0 & & & \\
\hline Antimony-125 & $\mathrm{pCi} / /$ & 6.96 & 0 & & & 7.07 & 0 & & & \\
\hline Barium-133 & $\mathrm{pCin}$ & 3.22 & 0 & & & 3.36 & 0 & & & \\
\hline Cerium-144 & $\mathrm{pCi} / 1$ & 18.10 & 0 & & & 17.33 & 0 & & & \\
\hline Cesium-134 & $\mathrm{pCi} / \mathrm{l}$ & 2.53 & 0 & & & 2.35 & 0 & & & \\
\hline Cesium-137 & $\mathrm{pCi} / \mathrm{l}$ & 2.52 & 100 & 4.92 & 7.25 & 2.73 & 100 & 5.43 & 5.31 & 6.84 \\
\hline Cobalt-57 & $\mathrm{pCi} / \mathrm{l}$ & 2.33 & 0 & & & 2.23 & 0 & & & \\
\hline Cobalt-58 & $\mathrm{pCi} / \mathrm{l}$ & 2.59 & 0 & & & 2.64 & 0 & & & \\
\hline Cobalt-60 & $\mathrm{pCi} / 1$ & 2.66 & 0 & & & 2.54 & 0 & & & \\
\hline Europium-152 & $\mathrm{pCi} / 1$ & 7.25 & 0 & & & 7.48 & 0 & & & \\
\hline Europium-154 & $\mathrm{pCi} / 1$ & 24.65 & 0 & & & 22.90 & 0 & & & \\
\hline Europium-155 & $\mathrm{pCi} / 1$ & 9.92 & 0 & & & 9.67 & 0 & & & \\
\hline Gross alpha & $\mathrm{pCi} / \mathrm{l}$ & 0.74 & 0 & & & 0.72 & 0 & & & \\
\hline Lead-212 & $\mathrm{pCi} / \mathrm{l}$ & 4.98 & 25 & & 30.10 & 5.02 & 25 & & & 8.48 \\
\hline Manganese-54 & $\mathrm{pCi} / \mathrm{l}$ & 2.40 & 0 & & 1.38 & 2.59 & 0 & & & \\
\hline Neptunium-239 & $\mathrm{pCi} / 1$ & 17.77 & 0 & & & 17.35 & 0 & & & \\
\hline Nonvolatile beta & $\mathrm{pCi} / 1$ & 1.37 & 100 & 2.22 & 2.82 & 1.47 & 75 & 2.39 & 2.24 & 3.13 \\
\hline Potassium-40 & $\mathrm{pCi} / 1$ & 28.80 & 50 & 28.41 & 45.60 & 23.40 & 50 & 27.30 & 23.55 & 45.40 \\
\hline Promethium-144 & $\mathrm{pCi} / /$ & 2.57 & 0 & & & 2.65 & 0 & & & \\
\hline Promethium-146 & $\mathrm{pCi} / \mathrm{l}$ & 3.44 & 0 & & & 3.31 & 0 & & & \\
\hline Ruthenium-106 & pCVI & 24.18 & 0 & & & 24.12 & 0 & & & \\
\hline Sodium-22 & pCill & 2.49 & 0 & & & 2.79 & 0 & & & \\
\hline Thorium-234 & $\mathrm{pCi} / /$ & 119.50 & 50 & 127.82 & 275.00 & 112.75 & 75 & 120.38 & 113.82 & 151.00 \\
\hline Tin-113 & $\mathrm{pCi} / \mathrm{l}$ & 3.17 & 0 & & & 3.30 & 0 & & & \\
\hline Yttrium-88 & $\mathrm{pCi} / \mathrm{l}$ & 2.82 & 0 & & & 3.12 & 0 & & & \\
\hline Zinc-65 & $\mathrm{pCi} / \mathrm{l}$ & 4.99 & 0 & & & 5.12 & 0 & & & \\
\hline Zirconium-95 & $\mathrm{pCl} / \mathrm{l}$ & 4.96 & 0 & & & 4.52 & 0 & & & \\
\hline
\end{tabular}

a $\mathrm{DL}=$ detection limit

N b Sample size $=4$. 
Table 9 (continued). Radionuclide and metal concentrations in Par Pond water. Samples were taken near the top and near the bottom. September 1995.

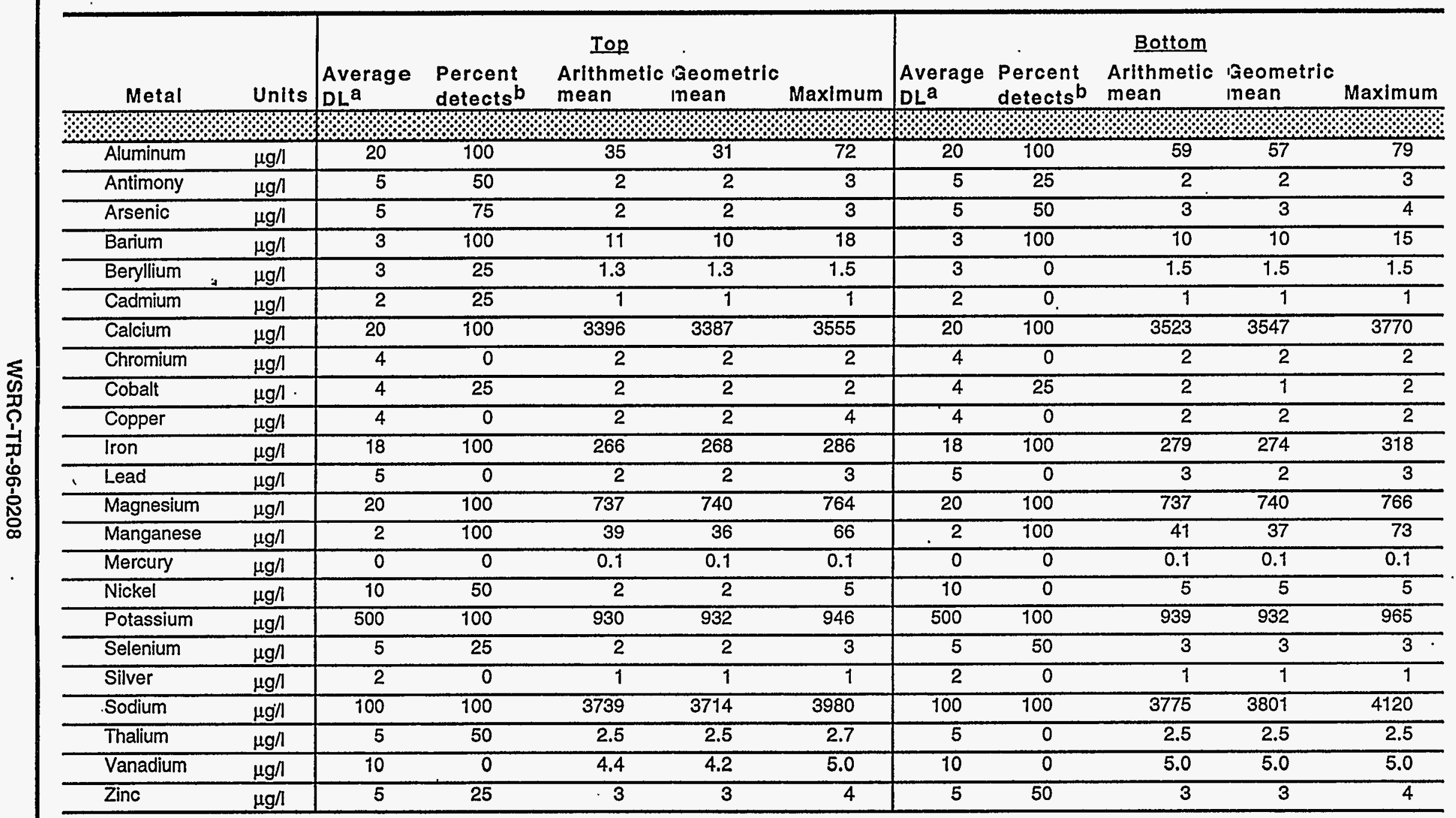

a DL $=$ detection limit

b Sample size $=4$. 


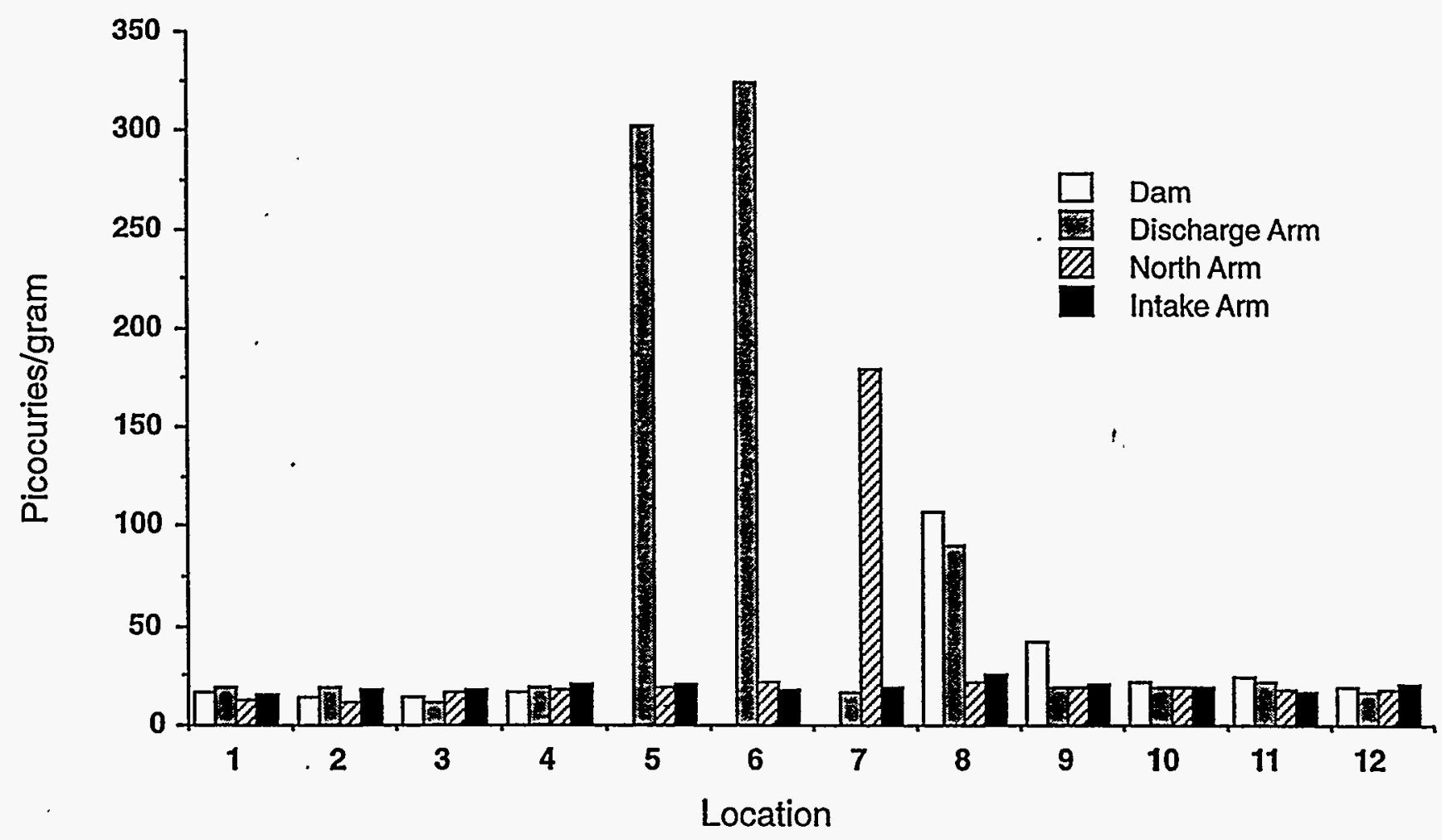

Figure 8. Cesium-137 sediment concentrations at different locations in Par Pond. Locations represent points on transects extending across the reservoir arm. The deepest areas were generally in the vicinity of locations 5-8.

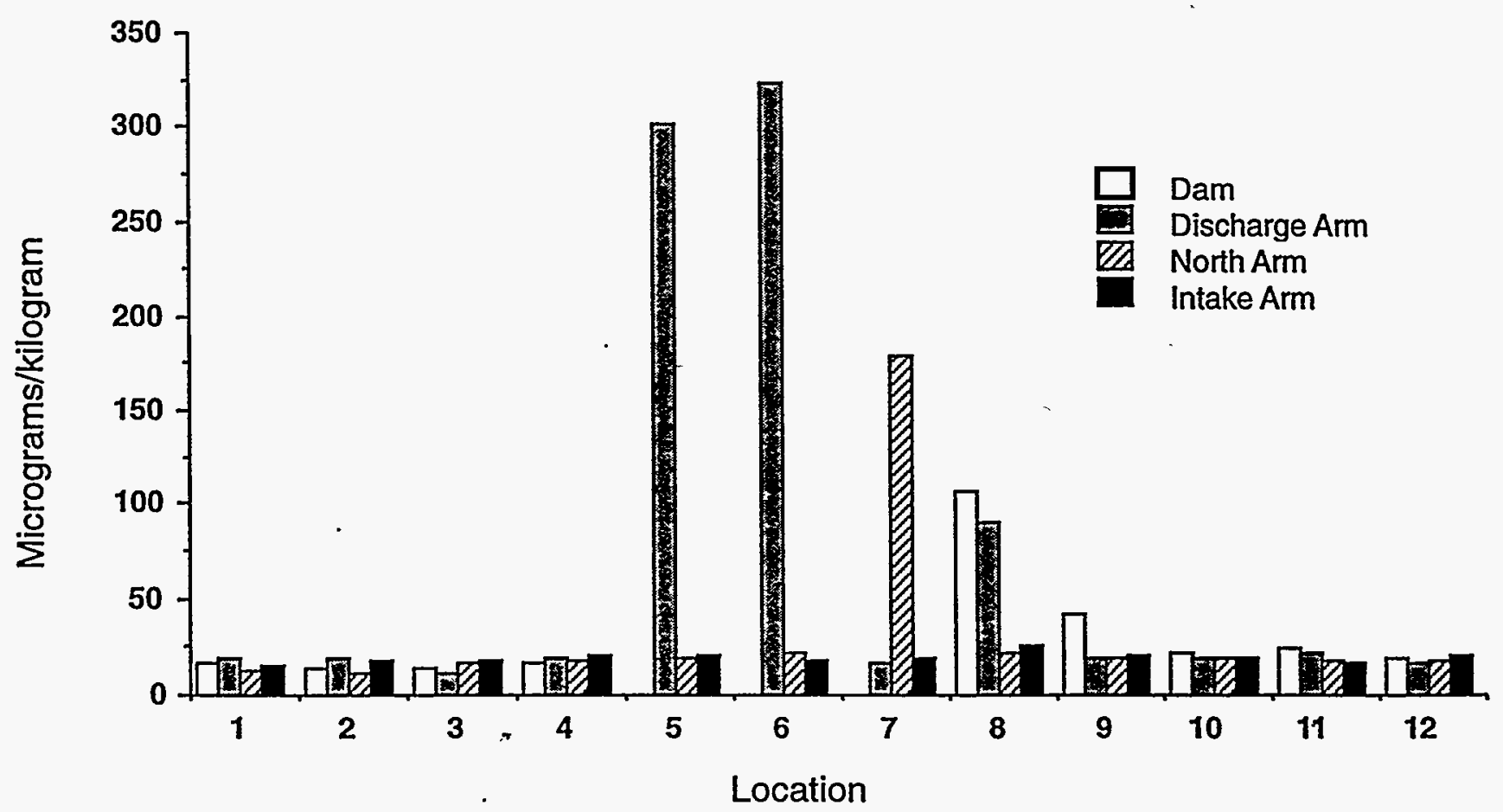

Figure 9. Total mercury sediment concentrations $(\mu \mathrm{g} / \mathrm{kg})$ at different locations in Par Pond. Locations represent points on transects extending across the reservoir arm. The deepest areas were generally in the vicinity of locations $5-8$. 
As a result of these benefits, winter drawdown followed by spring refill is a commonly used technique for managing reservoir fish populations.

Although winter drawdown followed by spring refill is often beneficial, other fluctuating water level scenarios can be detrimental to reservoir fish populations. Water level fluctuations during the spawning period (spring and early summer for most southeastern fishes) can dewater spawning areas, causing the loss of eggs and larvae: (Gaboury and Patalas 1984). Spring drawdowns can deprive littoral-zone species of essential spawning habitat and result in reproductive failure (Estes 1972). Extreme drawdowns can cause water chemistry changes that result in fish kills (Gaboury and Patalas 1984). Generally, moderate water level changes that mimic natural cycles of water level (increase in late winter and spring due to heavy rainfall and/or snowmelt and subsequent reductions in late summer through winter) are beneficial, presumably because southeastern fishes have evolved to take advantage of such changes. In contrast, unnatural water level regimes, such as extreme or frequent fluctuations or spring drawdowns, have deleterious effects.

Hydrologic models suggest that Par Pond water level will fluctuate by several feet following the shutdown of the river water distribution system (COE 1994). The water level will be largely dictated by rainfall, resulting in a general trend of a higher water level in the late winter and spring and a lower level from the late summer through midwinter. However, there will undoubtedly be some years with uncharacteristic water levels because of the partially random nature of weather patterns (e.g., fall hurricanes). Such water level fluctuations are unlikely to have inimical effects on the Par Pond fish community, and in years of high spring water levels, are likely to result in the production of unusually strong year classes. The rapid recovery of the Par Pond fish community following the extended 1991-1995 drawdown provides evidence of the resiliency of this community and its ability to recover from changes in water level, even when the timing and magnitude of such events are inimical.

Littoral zone vegetation constitutes an important habitat for many of the fish species in Par Pond. Water level fluctuations may cause the vegetation assemblage to change in terms of species composition, but is unlikely to cause large changes in overall vegetation coverage (H. E. Mackey; personal communication). Changes in vegetation may. have subtle indirect effects on the Par Pond fish community, but there is currently no reason to anticipate that these effects will be deleterious.

Data collected before and after the Par Pond drawdown and refill suggest that the refill had little effect on contaminant levels in the aquatic ecosystem. There was no evidence of long-term resuspension of contaminants in the water nor was there evidence of extensive redistribution of contaminants as a result of sediment movements (although localized downslope movements of contaminants on the exposed shoreline during the drawdown remains a possibility; Paller and Wike 1996). Also, as of September 1995, there was no evidence of increased mercury concentrations in Par Pond bass as a result of the refill. These data suggest that future water level fluctuations of several feet will neither significantly affect contaminant concentrations nor distribution patterns in the Par Pond aquatic ecosystem.

\section{Summary and Conclusions}

For the first 30 years of its existence, Par Pond received heated effluent from one or more nuclear reactors. It was also inadvertently contaminated with low levels of mercury and radionuclides, primarily cesium-137. Despite these impacts, Par Pond supported a diverse, self-sustaining, and relatively stable community of fishes generally similar to the fish communities found in other southeastern reservoirs. 
From 1991 to 1995, the water level of Par Pond was drawn down approximately 6 meters (20 feet), resulting in a $50 \%$ reduction in surface area, a $65 \%$ reduction in volume, and the temporary elimination of the littoral zone. The four-year drawdown adversely affected the Par Pond fish community as indicated by significant reductions in the average number of fish and number of fish species collected at electrofishing transects. However, these effects were temporary. Within seven months of Par Pond refilling to its former level, the number of fish species, number of fish, and relative abundance of fish had returned to pre-drawdown levels. However, the size structures of the fish populations differed from pre-drawdown size structures in that young individuals were more abundant and large individuals less abundant. The rapid recovery of the Par Pond fish community demonstrated its resiliency to the effects of water level changes. Factors that contributed to this resiliency included the ability of fish to rapidly recolonize newly inundated habitat, high reproductive capacity, and the rapid regrowth of aquatic vegetation, which provided cover for juvenile fishes in formerly exposed areas.

There was concern that erosion of exposed shoreline during the drawdown, possible resuspension of sediments during the refill, and biological and chemical changes associated with the drawdown and refill might result in greater contamination of Par Pond organisms. However, as of late 1995, there was no evidence of increased contaminant concentrations in Par Pond largemouth bass. Similarly, there was no evidence of increased contami- nant levels in Par Pond water nor of gross changes in the distribution of contaminants in the Par Pond sediments. As of late 1995, mercury levels in Par Pond largemouth bass were generally similar to those in Savannah River largemouth bass. However, cesium137 levels in Par Pond largemouth bass were higher than in largemouth bass from the Savannah River.

Current plans to shut down the SRS river water distribution system would cause the:water level of Par Pond to fluctuate by as much as several feet in response to seasonal changes in rainfall and evaporation. Considerable research on the effects of fluctuating water levels in other reservoirs indicates that fluctuations are not harmful and may even be beneficial if they are not extreme and match the fluctuations generally characteristic of a normal hydrologic cycle (i.e., high in spring and low in late fall and early winter). Fluctuations in the water level of Par Pond, because they would be determined largely by local weather patterns, would follow natural patterns, although there may be some years in which low water levels during the spring could reduce fish reproductive success. However, as the drawdown studies have demonstrated, such effects are likely to be temporary due to the resiliency of the Par Pond fish community. The drawdown studies also indicate that fluctuations in the water level of Par Pond are unlikely to increase contaminant levels in Par.Pond biota or result in long-term resuspension of contaminants in the water column. In summary, natural water level fluctuations of several feet in Par Pond are unlikely to deleteriously affect the Par Pond fish community. 


\section{References}

Alberts, J.J., L. J. Tilly, and T. J. Vigerstad. 1979. Seasonal cycling of cesium-137 in a reservoir. Science 203: 649-651.

Bagenal, T. 1978. Methods of assessment of fish production in fresh water. IBP Handbook No. 3. Blackwell Scientific Publications, London.

Bayley, P. B., and L. L. Osborne. 1993. Natural rehabilitation of stream fish populations in an Illinois catchment. Freshwater Biology 29: 295-300.

Bennett, G. W. 1970. Management of lakes and ponds. Van Nostrand Reinhold Co., New York, NY.

Boni, A. L. 1991. Inventory and concentration of Cs-137 and tritium in Par Pond and Lower Three Runs Creek system. SRL-ETS-91-0202. Interoffice memorandum from A. L. Boni to C. G. Hardin. Westinghouse Savannah River Company, Aiken, SC.

Carlander, K. D. 1969. Handbook of freshwater fisheries biology. Volume 1. The Iowa State University Press, Ames, IA.

Carlander, K. D. 1977. Handbook of freshwater fisheries biology. Volume 2. The Iowa State University.Press, Ames, IA.

Clugston, J. P. 1973. The effects of heated effluents from a nuclear reactor on species diversity, abundance, reproduction, and movement of fish. Ph. D. dissertation. University of Georgia, Athens, GA.

COE (U.S. Army Corps of Engineers). 1994. Par Pond reservoir level study. Project No. PC207194.001. U.S. Army Corps of Engineers, Charleston, SC.

Cone, R. S. 1989. The need to reconsider the use of condition indices in fishery science. Transactions of the American Fisheries Society 118: 510-514.
DOE (U.S. Department of Energy). 1994. Interim action proposed plan for the Par Pond unit. WSRCRP-92-1170. Savannah River Site, Aiken, SC.

EPA (U.S. Environmental Protection Agency). 1995. Supplemental guidance to RAGS: Region 4 Bulletins, Ecological Risk Assessment. U.S. Environmental Protection Agency, Region 4 Waste Management Division, Atlanta, GA.

Estes, R. D. 1972. Ecological impact of fluctuating water levels in reservoirs. Ecological impact of water resource development. Water, Man, and Nature Symposium. Bureau of Reclamation Report REC-ERC-72-17.

Gaboury, M. N. and J. W. Patalas. 1984. Influence of water-level drawdown on the fish populations of Cross Lake Manitoba. Canadian Journal of Fisheries and Aquatic Sciences 41: 118-125.

Gibbons, J. W., D. H. Bennett, G. W. Esch, and T. C. Hazen. 1978. Effects of thermal effluent on body condition of largemouth bass. Nature 274: 470-471.

Gilbert, R. O. 1987. Statistical methods for environmental pollution monitoring. Van Nostrand Reinhold, New York, NY.

Gladden, J. B., M. W. Lower, H. E. Mackey, W. L. Specht, and E. W. Wilde. 1985. Comprehensive cooling water study annual report. Volume III. Water quality. DP-1697. E. I. du Pont de Nemours and Co., Savannah River Laboratory, Aiken, SC.

Hamby, D. M. 1991. Par Pond soil and water concentration guidelines for Cs-137. SRL-ETS-910533. Interoffice memorandum. Westinghouse Savannah River Company, Aiken, SC.

Hinton, T. G. and F. W. Whicker. In press. A screening model approach to determine possible impacts to fish from historic releases of radionuclides. Science of the Total Environment. 
Hogan, D. C. 1978. Distribution and relative abundance of prey fish in a reservoir receiving heated effluent. Master's thesis. University of Georgia, Athens, GA.

Jagoe, C., B. Grasman, and J. T. Youngblood. 1994. Studies of the effects of drawdown of a reservoir on mercury levels in fish and other resident organisms. Presented at the International Meeting on Mercury as a Global Pollutant. Whistler, B.C. Canada.

Jannick, G. T. 1996. EDG/EMS position on how to determine risk to the maximally exposed individual from radionuclides in Savannah River fish. SRT-ETS-96-0023. Interoffice memorandum to W. J. Littrell. Westinghouse Savannah River Company, Aiken, SC.

Koch, J. W. II, F. D. Martin, and H. M. Westbury. 1996a. Par Pond refill water sampling. WSRCTR-96-0286. Savannah River Technology Center, Westinghouse Savannah River Company, Aiken, SC.

Koch, J. W. II, F. D. Martin, and G. P. Friday. 1996b. Results of Par Pond and L-Lake submerged sediment core characterization. WSRC-TR-960238. Savannah River Technology Center, Westinghouse Savannah River Company, Aiken, SC.

Lantz, K. E., J. T. Davis, J. S. Hughes and H. E. Schafer, Jr. 1964. Water level fluctuation - its effect on vegetation control and fish population management. Proceedings of the Southeastern Associations of Game and Fish Commissions 18: 483-494.

Liston, C. R., and S. Chubb. 1985. Relationships of water level fluctuations and fish. In: Coastal Wetlands. Lewis Publishers, Chelsea, MI.

Mackey, H. E., and R. S. Riley: 1996. Par Pond vegetation status summer 1995 - summary. WSRC-RP-95-1046. Westinghouse Savannah River Company, Aiken, SC.
Marasciulo, L. A., and M. McSweeney. 1977. Nonparametric and Distribution-free Methods for the Social Sciences. Brooks/Cole Publishing Co., Monterey, CA.

Martin, C. R. 1980. Movements, growth, and numbers of largemouth bass (Micropterus salmoides) in an unfished reservoir receiving heated effluent. Master's thesis. University of Georgia, Athens, GA.

Matthews, W. J. 1986. Fish faunal structure in an Ozark stream: stability, persistence, and a catastrophic flood. Copeia 2: 388-397.

Meffe, G. K., and A. L. Sheldon. 1990. Postdefaunantion recovery of fish assemblages in southeastern blackwater streams. Ecology 65: 523-528.

Newman, M. C., and A. Messier. 1994. Mercury bioaccumulation in mosquitofish (Gambusia holbrooki) sampled on and around the Savannah River Site. SREL-48 UC-66e. Savannah River Ecology Laboratory, Biogeochemical Ecology Division, Aiken, SC.

Nielson, L. A., and D. L. Joḩnson. 1983. Fisheries Techniques. American Fisheries Society. Bethesda, MD.

Nikolsky, G. V. 1963. The Ecology of Fishes. Academic Press, New York, NY.

Paller, M. H. 1996. L-Lake fish community and water chemistry. WSRC-96-0163. Westinghouse Savannah River Company, Savannah River Technology Center, Aiken, SC.

Paller, M. H., and B. M. Saul. 1985. Final report on the adult fish and ichthyoplankton of Par Pond and Pond B: January 1984-June 1985. ECS-SR-22. Environmental and Chemical Sciences, Inc., Aiken, SC.

Paller, M. H., and L. D. Wike. 1996. Potential ecological effects of contaminants in exposed Par 